Universidade de Brasília - UnB

Faculdade de Economia, Administração, Contabilidade, Ciência da Informação e Documentação - FACE

Departamento de Ciência da Informação e Documentação - CID

Gabriele da Silva Lopes

Mônica Coelho dos Reis

\title{
Necessidades de Informação dos usuários potenciais da Biblioteca Especializada do Zoológico de Brasília.
}

Brasília, DF

Julho-2009 
Universidade de Brasília - UnB

Faculdade de Economia, Administração, Contabilidade, Ciência da Informação e Documentação - FACE

Departamento de Ciência da Informação e Documentação - CID

Gabriele da Silva Lopes

Mônica Coelho dos Reis

\title{
Necessidades de Informação dos usuários potenciais da Biblioteca Especializada do Zoológico de Brasília.
}

\begin{abstract}
Monografia apresentada ao departamento de Ciência da Informação e Documentação como requisito parcial para obtenção do grau de Bacharel em Biblioteconomia.
\end{abstract}

Orientadora:

Profa $^{\text {. Dra }}$. Maria Alice Guimarães Borges

Brasília, DF

Julho-2009 
L864n

Lopes, Gabriele da Silva

Necessidades de Informação dos usuários potenciais da Biblioteca Especializada do Zoológico de Brasília / Gabriele da Silva Lopes e Mônica Coelho dos Reis. - Brasília, 2009.

$122 \mathrm{f}$; $29 \mathrm{~cm}$.

Monografia (graduação) - Universidade de Brasília, Departamento de Ciência da Informação e Documentação.

Orientadora: Prof $^{\mathrm{a}}$. Dr ${ }^{\mathrm{a}}$. Maria Alice Guimarães Borages.

1. Biblioteca Especializada. 2.Zoológico. 3.Necessidade de Informação. 4.Estudo de Usuário. I. Reis, Mônica Coelho dos. II.Título 
Título: Necessidades de Informação dos usuários potenciais da Biblioteca Especializada do Zoológico de Brasília

Alunas: Mônica Coelho dos Reis e Gabriele da Silva Lopes

Monografia apresentada ao Departamento de Ciência da Informação e Documentação da Universidade de Brasília, como parte dos requisitos para obtenção do grau de Bacharel em Biblioteconomia.

Brasília, 09 de julho de 2009.

Aprovada por:

Maria Alice Guimarães Bónges - Orientadora

Professora do Departamento de Ciência dá Informação e Documentação (UnB)

Doutora em Ciência da Informação

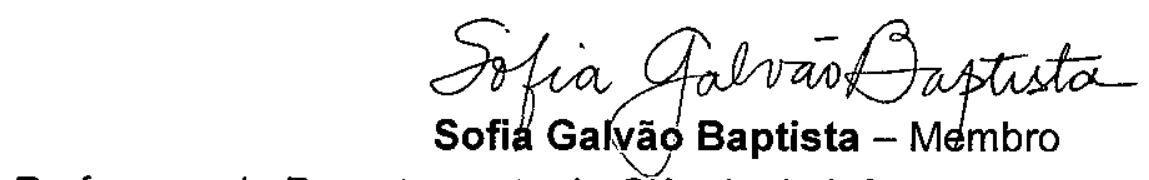

Professora do Departamento de Ciência da Informação e Documentação (UnB)

Doutora em Ciência da Informação

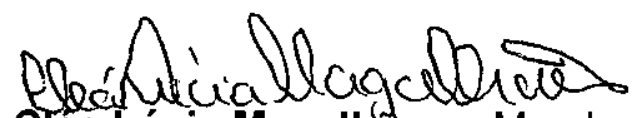

clea Lúcia Magalhäges - Membro

Veterinária do Zoológico 


\section{Dedicatória}

Dedicamos este trabalho a todas as crianças que freqüentam o Zoológico de Brasília aos futuros usuário da Biblioteca Especializada do ZOO - BEZOO. 


\section{Agradecimentos}

Agradecemos à Cléa Lúcia Magalhães, Superintendente do Zoológico de Brasília e a Beatriz Maria Cidade, Ouvidora do ZOO, por todo incentivo e apoio dado à realização deste trabalho. À Professora e nossa orientadora Maria Alice Guimarães Borges, pela dedicação, incentivo e sobretudo por nos dar ânimo para realização deste e do projeto relacionado. E aos nossos amigos que souberam compreender nossa ausência nos últimos seis meses. 
"Quando se sonha sozinho é apenas um sonho. Quando se sonha juntos é o começo da realidade".

Dom Quixote. 


\section{Resumo}

Esta monografia tem como resultado final uma proposta de serviços a serem oferecidos pela Biblioteca do Zoológico de Brasília, a fim de atender as necessidades informacionais dos frequentadores e funcionários/colaboradores da Fundação Jardim Zoológico de Brasília. O fundamento teórico aborda o conceito de Sociedade da Informação e do Conhecimento, apresenta conceitos de Biblioteca Especializada e de Disseminação da Informação, bem como de necessidades de informação de usuários de bibliotecas especializadas. Realiza-se o estudo de caso, mostrando o contexto sistêmico do Distrito Federal, do Governo do Distrito Federal, da Secretaria de Desenvolvimento Urbano e Meio Ambiente, da Fundação Jardim Zoológico de Brasília e de sua Biblioteca, alem de analisar e apresentar o perfil de seus usuários. O resultado da teoria com a experiência prática foi à base para sugerir os serviços a serem oferecidos pela Biblioteca Especializada do Zoológico de Brasília - BEZOO, que melhor irão atender aos seus usuários potenciais e aos objetivos da Fundação Jardim Zoológico de Brasília, como instituição que favorece e incentiva a pesquisa e o desenvolvimento social.

Palavras-chaves: Biblioteca Especializada; Zoológico; Necessidade de Informação; Estudo de usuário; Serviços de informação. 


\begin{abstract}
This monograph has as a final result a proposal of services to be offered by The Library of the ZOO from Brasília, aiming the service of the informational needs of the visitors/helpers from the Foundation Jardim Zoológico of Brazilia. The theoretic fundament comprehends the concept of the Information and Knowledge Society, presents concepts of the Specialized Library and of the Spread of Information, as well as the needs for information from the users of the specialized libraries. The case study is made, showing the systemic context of the Distrito Federal, from the Governo do Distrito Federal, of the Secretaria de Desenvolvimento Urbano e Meio Ambiente, of the Fundação Jardim Zoológico de Brasília and its Library, as well as analyzes and presents the profile of its users. The result of the theory with the practical experience was the base to suggest the services to be offered by the Biblioteca do Zoológico - BEZOO, that will better attend its potential users and the aims of the Fundação Jardim Zoológico de Brasília, as an institution that favors and encourages the search and the social development.
\end{abstract}

Keywords: Specialized Library; Zoo; Need for Information, User study, Information Services. 


\section{Lista de ilustrações}

Figura 0 - Paradigma orientado ao sistema e ao usuário...........................23

Figura 1 - Site do Zoológico de Sorocaba ...........................................31

Figura 2 - Indicadores demográficos e sociais do DF .................................35

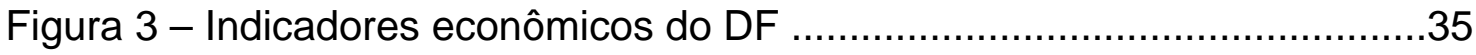

Figura 4 - Dados sócio-econômicos do DF ..................................................

Figura 5 - Regiões Administrativas do DF por densidade demográfica ...........36

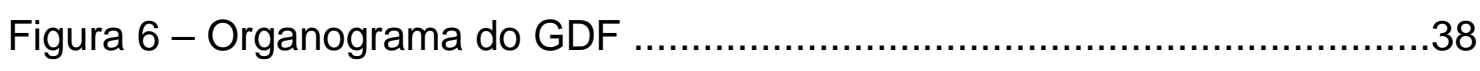

Figura 7- Organograma da SEDUMA ..............................................40

Figura 8 - Estrutura hierárquica do Zoológico de Brasília .............................42

Figura 9 - Quadro de atividades do projeto ................................................44

Figura 10 - Idade dos frequentadores entrevistados ...............................45

Figura 11 - Nível de instrução dos frequentadores ......................................46

Figura 12 - Dias de frequência ao ZOO ..........................................47

Figura 13 - Criação da Biblioteca do ZOO .........................................47

Figura 14 - Assuntos de interesse dos freqüentadores ...........................48

Figura 15 - Assuntos de interesse dos usuários que julgam desnecessária uma

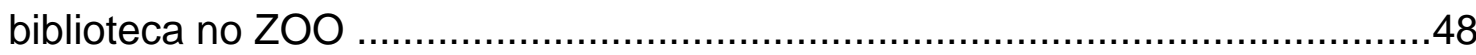

Figura 16 - Utilização de bibliotecas ...................................................49

Figura 17 - Sugestões do freqüentadores ........................................50

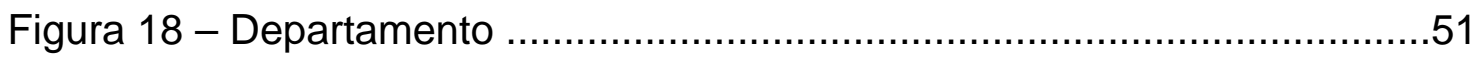

Figura 19 - Nível de instrução dos funcionários .....................................52

Figura 20 - Importância da Biblioteca ...............................................52

Figura 21 - Assuntos que devem constar no acervo ..................................53

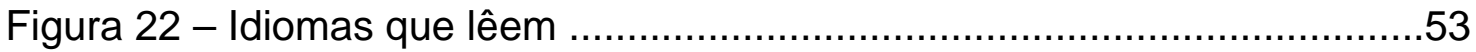

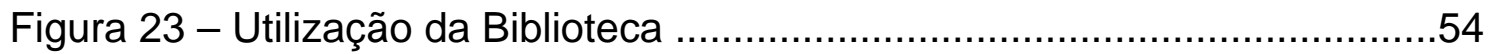

Figura 24 - Serviços a serem oferecidos ...............................................55 


\section{Sumário}

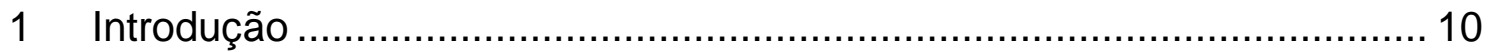

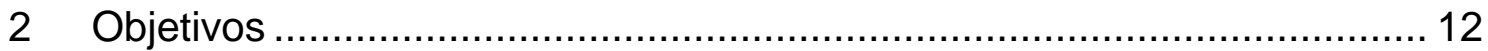

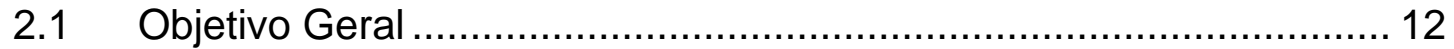

2.2 Objetivos Específicos.......................................................... 12

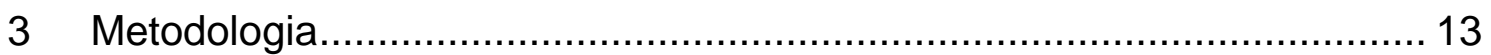

4 Revisão de Literatura ......................................................... 15

4.1 Sociedade da Informação e do Conhecimento .............................. 15

4.2 A biblioteca especializada ..................................................... 17

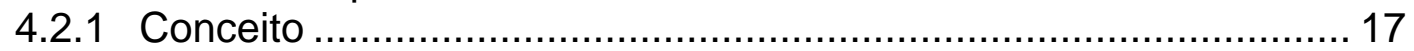

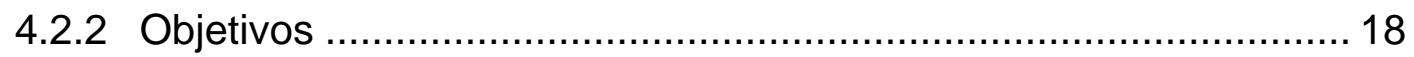

4.2 .3 Funções..................................................................... 19

4.2.4 Biblioteca especializada e Sociedade da Informação e do Conhecimento ............................................................................. 19

4.3 Estudo de Usuários em biblioteca especializada............................. 20

4.4 Necessidade de Usuários em biblioteca especializada ...................... 23

4.5 Disseminação da informação em biblioteca especializada.................. 26

4.6 Bibliotecas em Zoológicos ......................................................... 29

5 Estudo de Caso: A Biblioteca do Jardim Zoológico de Brasília, DF .......... 33

5.1 Distrito Federal - DF............................................................. 33

5.1.1 Dados Demográficos, Econômicos e Sociais ............................. 35

5.2 Governo do Distrito Federal - GDF ........................................... 37

5.3 Secretaria de Desenvolvimento Urbano e Meio Ambiente - SEDUMA 39

5.4 Fundação Jardim Zoológico de Brasília - ZOO .............................. 41

5.5 Biblioteca do Jardim Zoológico de Brasília - BEZOO......................... 43

5.6 Necessidades de informação dos usuários do ZOO - Análise dos

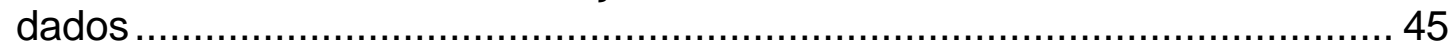

5.6 .1 Frequentadores ............................................................... 45

5.6.2 Funcionários e colaboradores .............................................. 51

5.7 Proposta para estabelecimento dos serviços de informação aos usuários da BEZOO............................................................................. 56

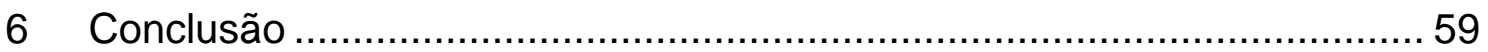

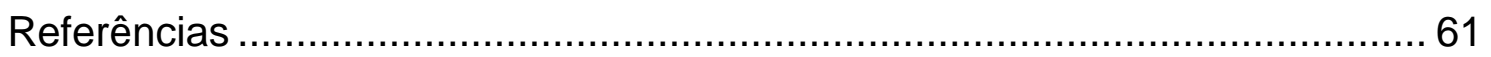

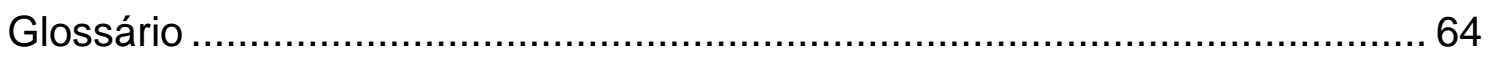

Anexo A - Projeto Executivo: Biblioteca do Zoológico de Brasília ..................65

Anexo B - Questionário Bibliotecas ....................................................117

Anexo C - Questionário Freqüentadores .............................................119

Anexo D - Questionário Funcionários ...............................................121 


\section{Introdução}

O mundo está vivenciando uma nova fase, a qual denomina de Sociedade da Informação e do Conhecimento, em que a informação se tornou um bem precioso, pois, desempenha um papel fundamental na produção de riquezas na sociedade tanto cultural, como social e econômica. A biblioteca, por sua vez, passa a desempenhar no século XXI, o grande papel de detentora e gestora do poder da informação, tendo como principal resultado, a sua disseminação. Nesse contexto fica clara a necessidade de uma unidade de informação nas organizações, que seja responsável por coletar, armazenar, organizar e disponibilizar essas informações.

A falta de uma unidade de informação nas organizações da sociedade atual demonstra quão importante é a existência de um centro de informação especializado na área a qual a instituição se destina, que sirva de suporte na realização dos trabalhos que competem à organização. Após estudos realizados, observou-se que a criação de uma Biblioteca Especializada seria uma das melhores soluções para tal problema, pois, a principal função da biblioteca especializada é o "suporte científico e tecnológico" na área a que se destina.

Em julho de 2007 a biblioteca existente no Zoológico foi vítima de um incêndio no qual todo seu acervo foi perdido. Contudo em dezembro do mesmo ano (2007), durante a comemoração dos cinqüenta anos do Zoológico de Brasília, foi apresentado (pelas autoras desta monografia juntamente com outra aluna de biblioteconomia, Deise Lourenço e sob orientação da Profa. Maria Alice Guimarães Borges) um Projeto de Implementação da Biblioteca do Zoológico de Brasília (Anexo A), o qual trás as diretrizes técnicas para sua construção e implementação e analisa o contexto em que a extinta biblioteca estava inserida, deixando claro o seu valor e importância para àqueles que a frequentavam. No mesmo dia o governador José Roberto Arruda assinou um documento confirmando a liberação de $R \$ 880.000,00$ (oitocentos e oitenta mil reais) destinados à construção da Biblioteca do ZOO. O Projeto de Implementação propõe a construção de uma Biblioteca que tenha como objetivo proporcionar cultura, lazer e informação na área de Meio Ambiente, Zoologia e áreas afins, para a população do Distrito Federal, que sirva de 
guardiã da memória institucional e que proporcione ao Zoológico (ZOO) a possibilidade de ser referência em educação e informação ambiental.

O projeto foi estruturado em 5 módulos, que se constituem nas fases do seu desenvolvimento: instalações físicas, estrutura organizacional, coleta, processos técnicos, disseminação e atendimento ao usuário.

Esta monografia corresponde ao Módulo 5 - Disseminação e Atendimento ao Usuário, pois viu-se necessário verificar as necessidades dos usuários potenciais dessa Biblioteca. Para que fosse possível propor os serviços a serem oferecidos que melhor atenderiam a tais necessidades. Esse é, portanto, o objetivo da presente monografia.

Conhecendo tal situação e após verificar a dificuldade de se encontrar literatura específica sobre Bibliotecas em Zoológicos, realizou-se uma revisão de literatura que aborda a sociedade da informação e do conhecimento e a biblioteca especializada, o estudo de usuário e a biblioteca especializada, a necessidade de usuários em biblioteca especializada, a disseminação da informação em biblioteca especializada. Foi levantada, também, a realidade das Bibliotecas em Zoológicos existentes no Brasil e em Portugal.

Embasado na Teoria Geral dos Sistemas, realizou-se um estudo de caso, que apresenta a história, os dados socioeconômicos e outros, do Distrito Federal, a história do Governo do Distrito Federal - GDF e sua estrutura administrativa, contendo a Secretaria de Desenvolvimento Urbano e Meio Ambiente - SEDUMA e a Fundação Jardim Zoológico de Brasília, além da história e situação atual da Biblioteca do Jardim Zoológico de Brasília. Foi analisada, por meio de pesquisa de campo, as necessidades dos frequentadores e dos funcionários/ colaboradores do Zoológico.

O resultado da teoria com a experiência prática foi à base para sugerir os serviços a serem oferecidos pela Biblioteca Especializada do Zoológico de Brasília - BEZOO, que melhor irão atender aos seus usuários potenciais. 


\section{Objetivos}

\subsection{Objetivo Geral}

Verificar as necessidades dos usuários da Biblioteca do Zoológico de Brasília, para propor os serviços a serem oferecidos, disponibilizando o acesso e uso às informações da área a que a Biblioteca se destina.

\subsection{Objetivos Específicos}

- Estudar o papel da Biblioteca Especializada na Sociedade da Informação e do Conhecimento, bem como as características de um estudo de usuários nessa Biblioteca.

- Explicitar o processo de Disseminação da Informação em Bibliotecas Especializadas.

- Conhecer a realidade de Bibliotecas em outros Zoológicos.

- Compreender o funcionamento da Fundação Jardim Zoológico de Brasília.

- Levantar, por meio de pesquisa de campo, as necessidades dos usuários potenciais da Biblioteca do Zoológico de Brasília.

- Propor serviços de informação a serem oferecidos pela Biblioteca do Zoológico, de acordo com as necessidades e expectativas de seus usuários. 


\section{Metodologia}

Este documento é composto por três partes, com suas subdivisões: revisão de literatura, estudo de caso e elaboração da proposta de serviços a serem oferecidos pela Biblioteca do Zoológico de Brasília - BEZOO.

Para realizar a revisão de literatura foram feitas pesquisas em livros, artigos de periódicos e páginas de Internet de assuntos relevantes para este trabalho. A revisão de literatura aborda os principais temas do documento, abrange o conceito de Sociedade da Informação e do Conhecimento, apresenta conceitos de Biblioteca Especializada e de Disseminação da Informação, bem como de necessidades de informação de usuários de bibliotecas especializadas, temas que são de suma importância para esta proposta de serviços.

$\mathrm{Na}$ revisão de literatura buscou-se informações sobre bibliotecas especializadas em zoológicos, porém nada foi encontrado. Diante dessa dificuldade foram feitos contatos telefônicos e por e-mail, e posteriormente foram enviados questionários para bibliotecas de zoológicos do Brasil e de Portugal. Tendo em vista a falta de resposta, decidiu-se realizar uma entrevista estruturada com os responsáveis pelas bibliotecas, localizadas no Brasil, via telefone (Anexo B). Conseguiu-se que duas bibliotecas, dos zoológicos de Belo Horizonte - MG e Sorocaba - SP, respondessem à entrevista.

Baseado na Teoria Geral dos Sistemas, o estudo de caso buscou apresentar a relação entre os sistemas: maior, intermediário e específico:

- Distrito Federal como o sistema maior: é apresentada a sua história, as principais características e os dados sociais, demográficos e econômicos. Os dados foram adquiridos no site do GDF.

- Existem neste caso três sistemas intermediários: o Governo do Distrito Federal - GDF, a Secretaria de Desenvolvimento Urbano e Meio Ambiente - SEDUMA e a Fundação Jardim Zoológico - ZOO. Os dados sobre o GDF e a SEDUMA foram obtidos no site do GDF. E o conteúdo sobre o ZOO foi extraído de documentos do Zoológico, bem como do site do mesmo. 
- Para melhor caracterizar o sistema específico, BEZOO, foi realizada uma pesquisa com os frequentadores e funcionários/colaboradores do Zoológico.

A fim de identificar as necessidades dos usuários potenciais da Biblioteca foram aplicados questionários a uma amostra de 100 frequentadores do ZOO e 25 funcionários e colaboradores, ver Anexos C e D.

Devido à falta de documentação sobre a extinta biblioteca, foi realizada uma entrevista semi-estruturada com a funcionária Núbia Feitosa que era responsável pelo funcionamento da Biblioteca. Por meio dessa entrevista foi possível obter informações a respeito da antiga biblioteca.

Segundo Baptista e Cunha (2007) existem três métodos mais frequentes de coleta de dados em estudo de usuários: questionário, entrevista e observação. A escolha do método está relacionada com o tipo de abordagem. Os questionários são utilizados em estudos quantitativos e a entrevista e observação em estudos qualitativos.

O questionário consiste em uma lista de questões propostas por um pesquisador junto aos respondentes. Optou-se por esse método na identificação das necessidades dos usuários por se tratar de um método rápido, barato e que atinge uma grande parte da população dispersa numa região extensa. Conforme Baptista e Cunha (2007) a entrevista é o método mais utilizado após o questionário. Ela pode ser: estruturada, semi-estruturada e não estruturada. Permite captar reações dos entrevistados e possibilita 0 esclarecimento de dúvidas. É um método mais caro, porém a obtenção dos dados é conseguida com riqueza de detalhes.

Por meio dos resultados dos questionários aplicados, aos funcionários e frequentadores, foi possível tabular os dados e analisá-los quantitativa e qualitativamente, pois ambos continham questões abertas. Esta questão facilitou a percepção das reações dos respondentes e permitiu o maior entendimento de suas necessidades. A partir dessa análise foram propostas sugestões de serviços a serem oferecidos pela Biblioteca do Zoológico de Brasília. 


\section{Revisão de Literatura}

\subsection{Sociedade da Informação e do Conhecimento}

Para melhor explicar o surgimento da Sociedade chamada da informação e do conhecimento será apresentada uma rápida abordagem das mudanças sociais ocorridas ao longo dos tempos.

Kenneth Boulding em O significado do século XX (apud BORGES, 2000, p.25) "classifica a vida humana em duas grandes épocas: a pré-civilizada, do nômade que adquire caracteres de civilização ao urbanizar-se, e a póscivilizada, que constitui a atual". Nessa primeira fase o homem prioriza a sobrevivência. Com o início da urbanização, cultivo de terra e ocupação de território surge a noção de "propriedade e sua valorização como elemento de diferenciação e de poder. Guerras e conflitos vieram comprovar que a posse da terra era fundamental para o exercício da força, do domínio e da existência" (JAMIL, 2000, p. 42).

Na segunda fase com a evolução da civilização aparece o capital e a valorização das riquezas, juntamente com a indústria, como pilares que ergueram e sustentam até hoje o capitalismo.

Segundo Jamil (2000, p. 43):

um conceito marcante nesse período foi o surgimento das corporações multinacionais que rapidamente tornaram-se uma face bem sucedida desta especialização do capitalismo, na medida em que adotavam uma forma abrangente como organizações que, muitas vezes, não se aplicavam exclusivamente aos territórios em si, mas ao poder e ao capital.

Com o advento da Internet e a facilidade de acesso aos serviços de telecomunicações iniciam-se os negócios baseados nas tecnologias de informação. O mercado comercial é atraído pela WWW (World Wide Web) e a troca de informações entre pessoas e organizações de qualquer parte do mundo se torna fácil e cada vez mais natural.

CASTELLS (1999, apud JAMIL, 2000, p. 45) defende que:

Uma nova economia surgiu em escala global nas últimas duas décadas. Chamo-a de informacional e global para indicar suas características fundamentais e diferenciadas e enfatizar sua interligação. É informacional porque a produtividade e a 
competitividade de unidades ou agentes nessa economia (sejam empresas, regiões ou nações) dependem basicamente de sua capacidade de gerar, processar e aplicar de forma eficiente a informação baseada em conhecimentos. É global porque as principais atividades produtivas, o consumo e a circulação, assim como seus componentes (capital, trabalho, matéria-prima, administração, informação, tecnologia e mercados) estão organizados em escala global, diretamente ou mediante uma rede de conexões entre agentes econômicos. É informacional e global porque, sob novas condições históricas, a produtividade é gerada, e a concorrência é feita em uma rede global de integração. E ela surgiu no último quartel do século $X X$ porque a Revolução da Tecnologia da Informação fornece a base material indispensável para esta nova economia.

A informação torna-se a base para a tomada de decisão. A alavanca do sucesso deixou de ser somente o dinheiro e passou a ser a informação. Para Toffler (1995, apud Borges, 2000) essa realocação de poder deu-se por meio da mudança no papel, na significação e na natureza do conhecimento. Bell (1978, apud NEHMY e PAIM, 2002), mesmo nos anos 1970, já afirma que os portadores do conhecimento serão as classes dominantes da sociedade.

Miranda (2007, p. 87) vem confirmar essa idéia afirmando:

a informação tornou-se a mais valiosa força de transformação do homem, ou seja, informação pode traduzir-se em poder. Esse poder da informação associado aos contemporâneos meios de comunicação de massa possui capacidade infinita de mudar culturalmente a sociedade como um todo. E a informação quando aplicada corretamente, contribui como instrumento de sucesso, caso contrário, pode levar ao fracasso, dependendo do seu emprego e a quem se destina.

Esse modelo atual de sociedade, onde a informação e o conhecimento são capazes de determinar o sucesso e o insucesso, o poder e a incapacidade é chamado de Sociedade da Informação e do Conhecimento.

Borges (2000, p. 29) caracteriza a sociedade da informação da seguinte forma:

- a grande alavanca do desenvolvimento da humanidade é realmente o homem;

- a informação é um produto, um bem comercial;

- o saber é um fator econômico;

- as tecnologias de informação e comunicação vêm revolucionar a noção de "valor agregado" à informação;

- a distância e o tempo entre a fonte de informação e o seu destinatário deixaram de ter qualquer importância; as pessoas não precisam se deslocar porque são os dados que viajam; 
- a probabilidade de se encontrarem respostas inovadoras a situações críticas é muito superior à situação anterior;

- as tecnologias de informação e de comunicação converteram o mundo em uma "aldeia global" (MacLuhan);

Esta era da informação e do conhecimento conseguiu transformar o mundo em uma grande sociedade, globalizada e globalizante, na qual a informação move o mercado e os desejos humanos.

\subsection{A biblioteca especializada}

Segundo Figueiredo (1979, p. 10), "as bibliotecas especializadas na forma como as conhecemos hoje em dia, começaram a surgir no início do século $\mathrm{XX}$, em resposta ao avanço crescente nas áreas de ciência e tecnologia".

\subsubsection{Conceito}

Alguns autores conceituam biblioteca especializada quanto ao acervo e outros quanto ao usuário ou acervo/usuário, dependendo do ponto de vista de seus trabalhos.

Para Miranda (2007), elas "se originam da necessidade de órgãos governamentais, universidades (bibliotecas setoriais) ou empresas [...]. Atuam como importantes agentes disseminadores dos conhecimentos necessários nos estudos e tomadas de decisões das instituições das quais fazem parte". Cezarino (1978) compartilha do mesmo pensamento. Para a autora "as bibliotecas especializadas são unidades pertencentes a instituições governamentais, particulares ou associações formalmente organizadas com o objetivo de fornecer ao usuário a informação relevante de que ele necessita, em um campo específico de assunto".

Para diferenciar bibliotecas especializadas das demais Ashworth (1967, apud SALASÁRIO, 2000, p. 106) foca o conteúdo do acervo, afirmando que "a biblioteca especializada é uma biblioteca quase exclusivamente dedicada à publicação sobre um assunto ou sobre um grupo de assuntos em particular. Inclui também coleções de uma espécie em particular de documentos". 
Conforme Figueiredo (1979, p. 10) as idéias dos autores, citados anteriormente, unem os conceitos de acervo específico e suporte informacional à organização quando diz que:

As bibliotecas especializadas são diferenciadas dos demais tipos de bibliotecas pela sua estrutura de orientação por assunto, e pelo fato de que as organizações as quais elas pertencem terem objetivos específicos, e estes objetivos, por sua vez, devem nortear todas as atividades da biblioteca.

Focando a satisfação do cliente como objetivo principal de uma unidade de informação, Carvalho (1991, apud SALASÁRIO, 2000, p. 107) "afirma que a biblioteca especializada é o local onde os usuários se encontram para solucionar problemas informacionais e trocar idéias".

Salvato (1998, apud SALASÁRIO, 2000) alerta que o papel da biblioteca especializada se baseia no "suporte científico e tecnológico" e por isso depende de constante atualização para atender a demanda. Ressalva ainda que ela "não deve estar isolada, mas em constante comunicação com outras fontes de informação e fazendo intercâmbio para assim, suprir as necessidades da instituição e/ou dos seus usuários".

Por sua vez, Salasário (2000, p. 108) conclui que "unindo-se acervo e usuário tem-se o conceito de biblioteca especializada, ou seja, uma unidade de informação com acervo especializado destinado à satisfação das necessidades informacionais de um público específico".

\subsubsection{Objetivos}

Depois de conceituar biblioteca especializada, cabe mencionar seus objetivos, que segundo Meltzer (1967, apud FIGUEIREDO, 1979), em qualquer situação ou localização, objetivam adquirir, organizar, manter, utilizar e disseminar materiais relacionados às atividades da organização a qual pertencem. Objetivos os quais devem ser coerentes e relacionados às outras ações da biblioteca, complementa Targino (1988). 


\subsubsection{Funções}

$\mathrm{Na}$ visão dos autores citados, as funções das bibliotecas especializadas estão orientadas para se alcançar os objetivos específicos da área em que atuam.

Para Figueiredo (1979, p. 11) constituem como suas funções:

- Desenvolvimento da coleção, de acordo com as necessidades da organização;

- Manutenção de catálogos, índices e referências sobre assuntos especializados;

- Disseminação da informação corrente através de: exposições, fornecimento de cópias, notificações pessoais $[\ldots]$;

- Empréstimo de livros e circulação automática de periódicos;

- Indexação e resumos de relatórios internos e de correspondência técnica;

- Manutenção de serviços de referência [...];

- Compilação de bibliografias e preparação de relatórios;

- Assistência editorial às publicações da organização;

- Serviços de tradução;

- Serviços personalizados de vários tipos.

Miranda (2007, p. 88) cita as funções da biblioteca especializada de uma forma mais sucinta e atualizada:

- Fornecer informação de forma rápida e eficaz, centrada em uma área do conhecimento, buscando atender as necessidades dos usuários;

- Realizar um tratamento exaustivo nos documentos, ampliando os recursos de recuperação da informação;

- Disseminar seletivamente a informação;

- Proporcionar o acesso a bases de dados especializadas na área de interesse da coleção;

- Permitir a recuperação aprofundada de informações sobre assuntos específicos da área.

Já Burstein et al. (1977 apud, SALASÁRIO, 2000, p. 111) "colocam que a biblioteca especializada tem funções mais específicas, como recreação, educação continuada e aperfeiçoamento profissional, cultural e social dos seus usuários".

\subsubsection{Biblioteca especializada e Sociedade da Informação e do Conhecimento}

$\mathrm{Na}$ Sociedade da Informação e do Conhecimento é a informação que move o mercado e quem a detém possui poder. Apesar de todos os avanços tecnológicos especificamente a Web, capaz de transmitir essa preciosa 
informação em segundos para qualquer lugar do mundo, as bibliotecas não perderam seu lugar, pelo contrário, ganharam seu espaço dentro das organizações, pois a fonte básica de informação é a informação registrada. Por isso o que Sass (1963, apud FIGUEIREDO, 1979, p. 13) dizia nos anos 1960 é válido até hoje:

Às três necessidades básicas da indústria moderna: homens, materiais e máquinas, foi acrescentada uma quarta: informação. Numa época caracterizada por rápidos avanços nos campos da ciência e da tecnologia, assim como também nas técnicas de gerência, a necessidade pela informação sobre o mais recente acontecimento, tornou-se essencial para organizações de negócios que desejam obter a liderança na sua área de atuação. O que leva o mundo industrial, cioso do dólar gasto, a dispender em livros e bibliotecas? A resposta reside no simples fato de que, para a indústria operar, é essencial grande diversidade de informação. Apesar dos computadores avançados e de outros instrumentos eletrônicos, a fonte básica de informação - além da experimentação original - é, ainda, a palavra escrita.

\subsection{Estudo de Usuários em biblioteca especializada}

Antes de falar em estudo de usuários é necessário saber o que caracteriza um usuário. Neveling e Wersig (1976, apud TERUEL, 2005) definem usuário como a pessoa ou organização que necessita de informação especializada de um centro ou serviço de informação existente ou em fase de planejamento. Precisamente, do ponto de vista dos sistemas de informação, pode-se definir dois tipos de usuários: os potenciais e os reais.

Para Teruel (2005) os usuários potenciais são aqueles que carecem de informação, independentemente dessa necessidade se traduzir ou não na consulta de uma fonte de informação, na solicitação de informação a outro indivíduo ou na demanda a um sistema de informação. A autora ainda afirma que usuários potenciais são aqueles que constituem a população que deveria ser atendida por aquele sistema de informação. Portanto, o funcionamento correto desse sistema dependerá do grau em que este seja capaz de adaptarse aos seus requisitos e, para isso, conhecer suas necessidades de informação, se torna um item imprescindível.

Ainda segundo Teruel (2005), o estudo de usuários é um processo de pesquisa em que seus resultados permitem planejar e melhorar os sistemas de 
informação. Esclarece ainda que a observação sistemática do usuário oferece uma ferramenta de grande valor para tomar decisões.

Silva (1990, p. 80) complementa dizendo que estudo de usuário pode ser definido como: "uma investigação que objetiva identificar e caracterizar os interesses, as necessidades e os hábitos de informação dos usuários reais e/ou potenciais de um sistema de informação" a partir do ambiente em que ele está inserido. Tal termo passou a ser utilizado com maior freqüência a partir da segunda metade do século XX, e possui duas vertentes: a abordagem tradicional e a abordagem alternativa.

Desde a década de 1960, a temática estudo de usuários vem sendo pesquisada e, ao longo dos anos, houve mudanças em seus métodos, objetivos e foco de pesquisas. A preocupação estava em estudar a freqüência de uso de determinado material de forma quantitativa, e não o comportamento informacional dos usuários. Sua pesquisa se caracterizava pela utilização de técnicas estatísticas tanto na fase de coleta, quanto no tratamento dos dados coletados.

Nos anos 1970, sentiu-se a necessidade de identificar como a informação era obtida e usada. Os estudos descobriram que a facilidade de acesso determina o uso e que a velocidade de resposta do sistema é um fator importante da efetividade.

Na década de 1980, apareceu a preocupação com a automação e o planejamento de serviços e sistemas de informação que fossem capazes de satisfazer as necessidades dos usuários, apesar dos problemas em identificar tais necessidades. A partir daí um novo paradigma para o termo estudo de usuários passou a ser verificado. Até a década de 1980, os pesquisadores utilizavam a abordagem tradicional com foco nos sistemas de informação, verificando como eram utilizados, quais as dificuldades e a satisfação com o seu uso. Os usuários deveriam utilizar o sistema exatamente como havia sido projetado, tendo que se adaptar a seus mecanismos de recuperação da informação, ao invés de moldar esses mecanismos às suas características particulares. Na fase de coleta e avaliação, a abordagem tradicional detém-se na observação de grupos de usuários, separados por região demográfica, faixa etária, sexo, escolaridade e outros, e não em suas vivências e características individuais. 
A partir da década de 1980, passou a ser levado em consideração o usuário como objeto de estudo. Ele deixa de ser um mero informante nas unidades de informação e passa a ser o ponto principal da pesquisa. Nessa nova abordagem, chamada de abordagem alternativa o pesquisador busca compreender a necessidade do usuário, respeitando sua individualidade para otimização do sistema de informação e melhor atendimento quanto as suas necessidades. O usuário passa a ser visto como razão fundamental dos serviços de informação e começa a ser estudado dentro do sistema social, político, econômico e outros que possam afetá-lo, levando-se em conta sua motivação e orientação profissional, principalmente. São analisadas as características de cada indivíduo, buscando chegar às cognições comuns a maioria deles.

O ser humano cria sua própria realidade e tem seus próprios estoques internos de informação, os quais são usados para compreender as informações externas e as diferentes situações em que os indivíduos se encontram em um dado momento. Ao contrário, o que estivemos procurando por décadas foi explicar as diferenças entre os usuários como simples decorrência de influências sociológicas e demográficas, estilo de vida e especificidade do trabalho (DERVIN e NILAN, 1986 apud FERREIRA, 1995, p. 3).

"Entretanto, comportamento de busca e uso de informação são também modelados pelo estilo cognitivo do indivíduo, isto é, sujeito ativo internamente versus ativo externamente, sistemático versus intuitivo e criativo versus menos criativo" de acordo com Rouse e Rouse (1984, apud FERREIRA, 1995, p. 3) e esse é o veio da abordagem alternativa. Os sistemas de informação devem ser modelados de acordo com o usuário.

Segundo Dervin e Nilan (1986, apud FERREIRA, 1995, p. 6), estes novos estudos de comportamento de usuários se caracterizam por:

1) observar o ser humano como sendo construtivo e ativo;

2) considerar o indivíduo como sendo orientado situacionalmente;

3) visualizar holisticamente as experiências do indivíduo;

4) focalizar os aspectos cognitivos envolvidos;

5) analisar sistematicamente a individualidade das pessoas;

6) empregar maior orientação qualitativa.

Dervin e Nilan (1986) estabelecem a dualidade das duas perspectivas (tradicional e alternativa), descrevendo uma série de aspectos que evidenciam a mudança de paradigma. Em linhas gerais, o paradigma alternativo frente ao 
tradicional considera a informação do ponto de vista subjetivo, tendo o usuário como ente ativo e sistemático e a conduta informativa dentro de um contexto situacional e global, observada de um ponto de vista cognitivo, conforme apresenta a Figura 1. Além disso, introduz o uso de métodos qualitativos que, em linhas gerais, pretende compreender, o mais profundamente possível, um fenômeno ou uma situação determinada (TERUEL, 2005, p. 87).

\begin{tabular}{|l|l|}
\hline $\begin{array}{l}\text { Paradigma orientado ao sistema } \\
\text { Tradicional }\end{array}$ & $\begin{array}{l}\text { Paradigma orientado ao usuário - } \\
\text { Alternativo }\end{array}$ \\
\hline Informação objetiva & Informação subjetiva \\
\hline Usuário passivo & Usuário ativo \\
\hline Transituacional & Situacional \\
\hline Visão atomística da experiência & Visão holística da experiência \\
\hline Conduta externa & Cognições internas \\
\hline Individualidade caótica & Individualidade sistemática \\
\hline Metodologia quantitativa & Metodologia qualitativa \\
\hline Fonte: DERVIN e NILAN, 1986 apud TERUEL, 2005, p. 87
\end{tabular}

Figura 0 - Paradigma orientado ao sistema e ao usuário

A partir da utilização dessa abordagem alternativa nos estudos de usuários, ficou constatada a importância do conceito de necessidade da informação. A natureza das pessoas, como elas agem, e a natureza da informação, como ela auxilia tornam-se as questões nevrálgicas dos estudos recentes.

\subsection{Necessidade de Usuários em biblioteca especializada}

A educação é, indiscutivelmente, um dos fatores de maior importância para o desenvolvimento econômico e social de um país, e é a educação que incita nos indivíduos a necessidade de obter informação, o que nos leva a constatar que o ser humano raramente busca informação como um fim em si mesmo. Ela é parte de um processo de tomada de decisão, solução de problemas ou alocação de recursos. Na sociedade da informação são inúmeras as fontes de informação disponíveis, porém a biblioteca especializada é a unidade de pesquisa mais completa na área a que ela se destina. Como afirma Volpato e Borenstein (2000) é na biblioteca que o usuário será capaz de 
encontrar a maior gama de matéria-prima para seu desenvolvimento e da sociedade, pois a mesma tem como principal função, suprir as necessidades informacionais da instituição a que pertence e seus usuários. A biblioteca pode ser vista como uma organização de sistema aberto, ou seja, que interage com um sistema maior chamado sociedade.

O conceito de necessidade de informação tem sido um aspecto amplamente discutido desde os primeiros trabalhos que apresentaram uma perspectiva teórica dos estudos da necessidade e uso da informação.

Taylor (1968, apud TERUEL, 2005) definiu as necessidades de informação do ponto de vista de um usuário que faz uma demanda a um bibliotecário de referência. Ele define quatro níveis de necessidade de informação segundo o grau de consciência do usuário:

- Necessidade visceral: necessidade de informação não expressa. Não existe na experiência da pessoa que realiza uma pergunta e pode ser uma vaga insatisfação. Provavelmente não é expressa em termos lingüísticos, e mudará na forma, qualidade e consistência com o acesso e assimilação de mais informação.

- Necessidade consciente: descrição mental consciente de uma área de indecisão mal definida. Provavelmente é uma valoração ambígua e confusa. Nesse nível de necessidade a pessoa pode falar com outras para centrar a questão, desaparecendo assim a ambigüidade e a confusão.

- Necessidade formalizada: é uma declaração formal da necessidade. Nesse nível a pessoa pode realizar uma valoração racional e qualificada de sua pergunta e, portanto, expressá-la formalmente.

- Necessidade comprometida: a pergunta traduzida à linguagem do sistema. A pergunta é refeita de acordo com o que o sistema pode proporcionar.

Conforme Heemann (1996 apud VOLPATO, 2000, p. 2):

as necessidades de informações das organizações como um todo e das pessoas da organização, de modo particular, são aspectos fundamentais para os processos de tomada de decisão que afetam o meio ambiente interno e externo, garantindo ou não a sobrevivência dessa organização e de seus membros 
O estudo sobre a necessidade de informação de uma biblioteca especializada se faz importante porque, as bibliotecas como organização não vivem isoladas e não são auto-suficientes, elas funcionam dentro de um contexto, do qual dependem para cumprir sua responsabilidade social. As necessidades, segundo Lipetz (1970 apud SILVA, 1990, p. 83) variam com o tempo, uso, propósito, localização e outros.

Ao se buscar compreender o que seja necessidade de informação, devese levar em consideração a individualidade do usuário a partir do "modelo dos fatores influenciáveis" citados por Allen (1989) no qual, experiência, faixa etária, nível educacional, estilos cognitivos e orientação individual se tornam características determinantes para a compreensão da necessidade de informação. Também é dada atenção para o tempo e espaço específicos experimentados pelo mesmo, valendo a ressalva de que, ao mesmo tempo em que eles enquanto pessoas se movem no tempo e espaço, tendo suas próprias experiências, existe também a grande similaridade entre as situações encontradas. Por isso, o estudo sobre necessidade de informação chega a ser complexo devido às divergências conceituais, à falta de metodologias eficazes para estudar as necessidades e usos da informação, o que pode ser explicado pela grande descontinuidade informacional a qual os seres humanos estão sujeitos e pela mutabilidade das necessidades, o que faz com que os usuários a cada hora e minuto possuam necessidades informacionais diferentes que mudam em função do contexto.

Silva (1990, p. 81) diz que:

os objetivos do estudo de necessidades e usos de informação podem estar dentre as seguintes:

- a explanação do fenômeno observado de uso ou necessidade expressa de informação;

- previsão de instâncias de uso da informação;

- o controle e, através deste, o aperfeiçoamento da utilização da informação via manipulação de condições especiais;

- a descrição do uso observado de informação;

- a definição de conceitos convenientes e apropriados para descrição e divulgação do uso de informação;

- a teorização das relações causal ou quantitativa entre uso de informação e fatores associados.

Enfim, Bettiol (1990, p. 67) conclui seu estudo dizendo que: 


\begin{abstract}
Uma conclusão mais plausível para uma definição sobre necessidade de informação é a de que variam de grau de intensidade de uma para outra pessoa. Elas são independentes na sua essência, nas diversas situações que se apresentam a uma pessoa. Podemos então considerar uma necessidade de informação como uma premência de saber, compreender ou descrever um determinado assunto, premência essa surgida de uma motivação, com um objetivo de obter uma visão mais clara e mais eficiente de uma realidade surgida no ambiente sócio-político-cultural que afeta o usuário.
\end{abstract}

Contudo, podemos afirmar que os diferentes tipos de usuários possuem necessidades de informação diferenciadas e por isso, demandam, da biblioteca que utilizam, serviços e atendimento específicos para seu perfil.

\title{
4.5 Disseminação da informação em biblioteca especializada
}

No cenário em que vivemos uma das mais importantes forças capaz de transformar o homem é a informação e para que essa transformação ocorra é necessário que o homem tenha acesso à informação, para assim ser capaz de transformá-la em conhecimento. Tal acesso só é possível por meio da disseminação da informação. Oliveira (2000) vem complementar essa idéia dizendo que "a disseminação da informação tem papel importante na construção do conhecimento e na formação da cidadania. Assim, essa sociedade é um novo ambiente global baseado em comunicação, informação, conhecimento e aprendizagem".

Para Lara e Conti (2003, p. 26)

\begin{abstract}
Disseminar informação supõe tornar público a produção de conhecimentos gerados ou organizados por uma instituição. A noção de disseminação é comumente interpretada como equivalente à de difusão, ou mesmo de divulgação. Assume formas variadas, dirigidas ou não, que geram inúmeros produtos e serviços, dependendo do enfoque, da prioridade conferida às partes ou aos aspectos da informação e dos meios utilizados para sua operacionalização.
\end{abstract}

Oliveira (2000) dá a significação de disseminação conforme o termo é usado na Biblioteconomia, "a palavra disseminar é entendida, em muitos estudos na área da Biblioteconomia como difundir, espalhar, semear". E "como disciplina pode ser entendida tanto como ramo do conhecimento como matéria de ensino". Ainda usando as palavras de Oliveira (op. cit), "a disseminação da informação como área do conhecimento é antiga e considerada por muitos 
autores, como o ato de levar a informação ao usuário por meio dos canais de comunicação",

\begin{abstract}
Dito de outro modo, falar em transferência da informação via serviços de disseminação de informações - distribuição física ou virtual de documentos e dados - supõe considerar que os benefícios dessa ação se relacionam diretamente às possibilidades de geração do conhecimento. Caso contrário, há apenas divulgação unilateral que atinge heterogeneamente o conjunto da sociedade. (LARA; CONTI, (2003, p. 27)
\end{abstract}

Ou seja, para um serviço eficiente de disseminação da informação, cujo objetivo é gerar conhecimento, é necessário que se conheça o usuário, já que o conhecimento e indissociável do indivíduo.

Lara e Conti (2003, p. 27) destacam a importância de se pensar no perfil do usuário/receptor, segundo eles "enfatizar os serviços de disseminação de informações no emissor, ignorando as características de seu público, ou concebê-lo em sua condição supostamente potencial, valendo-se de referências imaginadas ou idealizadas, não corrobora seu êxito".

Um serviço específico da disseminação da informação que está totalmente voltado ao usuário - e é realizado pensando nele - é a Disseminação Seletiva da Informação (DSI). A DSI foi idealizada por Hans Peter Luhn em 1958. Para Luhn (1961, apud SOUTO, 2006b, p. 7) a DSI é o:

Serviço dentro de uma organização que se refere à canalização de novos itens de informação, vindos de quaisquer fontes para aqueles pontos dentro da organização, onde a probabilidade de utilização, em conexão com interesses ou trabalhos carentes, é grande.

1.

Luhn caracteriza a DSI como um serviço oferecido dentro de uma organização para outras partes da mesma, já Souto (2006a, p. 60) conceitua-a de uma forma mais abrangente: "A Disseminação Seletiva da Informação (SDI) é um serviço que encaminha, periodicamente, uma relação de informações sobre a temática de interesse dos usuários cadastrados no serviço".

Amstel (apud SOUTO, 2006b, p. 7) descreve a Disseminação Seletiva da Informação como "um processo simples: verificar as demandas, coletar, tratar e distribuir as informações num fluxo contínuo". 
Apesar de ser frequentemente confundida com busca automatizada, a DSI pode ser oferecida manual ou eletronicamente, porém, manualmente não possui a mesma facilidade e eficiência que a DSI automatizada.

Segundo Souto (2006b, p. 7) "No contexto atual, é possível considerar a Disseminação Seletiva da Informação equivalente aos serviços de notificação corrente".

A partir dessa comparação pode-se destacar como componentes básicos de um serviço de DSI: "bases de dados, perfis de interesses dos usuários, notificações, retroalimentação e fornecimento de documentos" (ROWLEY, 2002 apud SOUTO, op. cit.).

A definição do perfil de usuários é um ponto importante para a prestação de um bom serviço de DSI, bem como de qualquer serviço prestado por uma biblioteca especializada. Nocetti (1980, p. 24) define o perfil de usuário "como o conjunto de indicadores que caracterizam as necessidades informacionais dos usuários". Longo (1978 apud SOUTO, 2006b, p. 62) indica como se obter o perfil do usuário, para a autora:

a melhor forma de se construir um perfil é através de uma entrevista pessoal com o usuário, na qual é feita uma narração por escrito de seu campo de atuação onde também são submetidas palavras-chave e referências que melhor definam o seu interesse específico.

Em seu estudo Souto (2006a, p. 71) identifica três modelos diferentes de elaboração de perfil de usuários:

- SDI de perfil individualizado (o usuário exterioriza, isoladamente - sem discussão com um profissional da informação - suas necessidades);

- SDI de perfil direcionado (o usuário determina seu perfil a partir de opções pré-estabelecidas: assuntos, títulos de periódicos); e o

- $\quad$ SDI de perfil reproduzido a partir de estratégias de busca.

O mesmo autor ainda conclui que:

A interação usuário/sistema tendo o profissional da informação como mediador, fazendo ou não uso de recursos tecnológicos, pode contribuir em todos os modelos de SDI. Seja para ajudar na exteriorização das necessidades (modelo de perfil isolado), na seleção de áreas e títulos de periódicos (perfil direcionado) ou na elaboração de estratégias de pesquisa (perfil reproduzido) a interação pode facilitar as atividades de representação/interpretação. 
Bax et al. (2005 apud SOUTO, 2006b, p.7) defende a interação usuário/sistema no que diz respeito a serviços de DSI, afirmando que:

\begin{abstract}
Um requisito importante para serviços de DSI é a personalização, que, por sua vez, depende de interação privilegiada com o usuário, que deve prover informações explicitamente ou implicitamente pela própria utilização do sistema. Nesse último caso, o sistema observa o comportamento de uso do usuário.
\end{abstract}

Considerando que o usuário é o maior beneficiado com a DSI, cabe enumerar algumas das vantagens para o mesmo. Segundo Borba (1973 apud SOUTO, op. cit.) a DSI proporciona ao usuário:

emprego mais eficiente de seu tempo nas atividades de informação; atualização constante acerca de novos progressos em sua área de interesse; maior acesso à informação; complementação de sua educação formal, e redução do nível de obsolência técnica.

Oliveira (2000) analisa o serviço de Disseminação da Informação do ponto de vista da gestão da informação, comentando que:

no processo de gerenciamento da informação, observamos que a área da administração vem incluindo a disseminação, com o objetivo de distribuir a informação aos que necessitam dela, com a necessidade de saber se a informação adequada foi recebida e distribuída de maneira correta, e se houve treinamento ao uso dela.

Por fim, pode-se afirmar que:

Na sociedade da informação e do conhecimento a disseminação da informação se preocupa com o usuário e suas necessidades para a geração de novos conhecimentos, a fim de melhor entender e explicar a gestão nos sistemas e unidades de informação, através das buscas nas bases de dados no entendimento global da organização (OLIVEIRA, 2000).

\title{
4.6 Bibliotecas em Zoológicos
}

Para conhecer a realidade das Bibliotecas existentes em Zoológicos, foi elaborado um questionário composto de dezessete questões, a serem aplicados nestas bibliotecas. Após levantamento realizado, verificou-se a existência de aproximadamente cinco bibliotecas/centros de documentação no Brasil e duas em Portugal. 
Os questionários foram enviados, via correio eletrônico para as seguintes bibliotecas: Biblioteca do Zoológico de Sorocaba - SP, Centro de Documentação do Zoológico de Belo Horizonte - MG, Biblioteca do Zoológico de São Paulo, Biblioteca do Zoológico de Lagos - Portugal, e para a Biblioteca do Jardim Zoológico de Lisboa - Portugal. Foi dado o prazo de quatro semanas para receber as respostas dos questionários, porém não se obteve nenhuma resposta via e-mail, logo, optou-se por ligar e fazer a entrevista estruturada por telefone com as bibliotecas localizadas no Brasil (Anexo B).

Apenas duas bibliotecas responderam à entrevista, a Biblioteca do Zoológico de Sorocaba e o Centro de Documentação do Zoológico de Belo Horizonte.

\section{Biblioteca do Zoológico de Sorocaba:}

A entrevista foi realizada com a assistente administrativa Roberta. Segundo ela, a biblioteca não possui recursos financeiros próprios e não tem autonomia sobre os recursos a ela destinados. É mantida pela Prefeitura Municipal de Sorocaba. A biblioteca só possui uma funcionária, ela própria, que é responsável pela realização de todos os serviços. Possui um acervo de 3.700 títulos entre livros e periódicos, 206 jogos, 265 DVD’s e 25 kits ecológicos.

Não oferecem o serviço de empréstimo de livros, que são disponibilizados para consulta local, sendo permitida a cópia. Somente é liberado o empréstimo de kits ecológicos e jogos para escolas e os animais empalhados para os funcionários do Zoológico. O público alvo são os usuários externos, que abrangem desde estudantes primários a universitários. A biblioteca não é informatizada e a aquisição do acervo é feita por meio de compra e doação.

O sistema de classificação utilizado é a Classificação Decimal Universal CDU e não possui vocabulário controlado. Segundo Roberta, os principais assuntos solicitados na biblioteca são: zoologia e educação ambiental. 
O único meio de divulgação da Biblioteca é o site do Zoológico de Sorocaba, Figura 1, onde consta uma lista dos livros e periódicos do acervo da biblioteca.

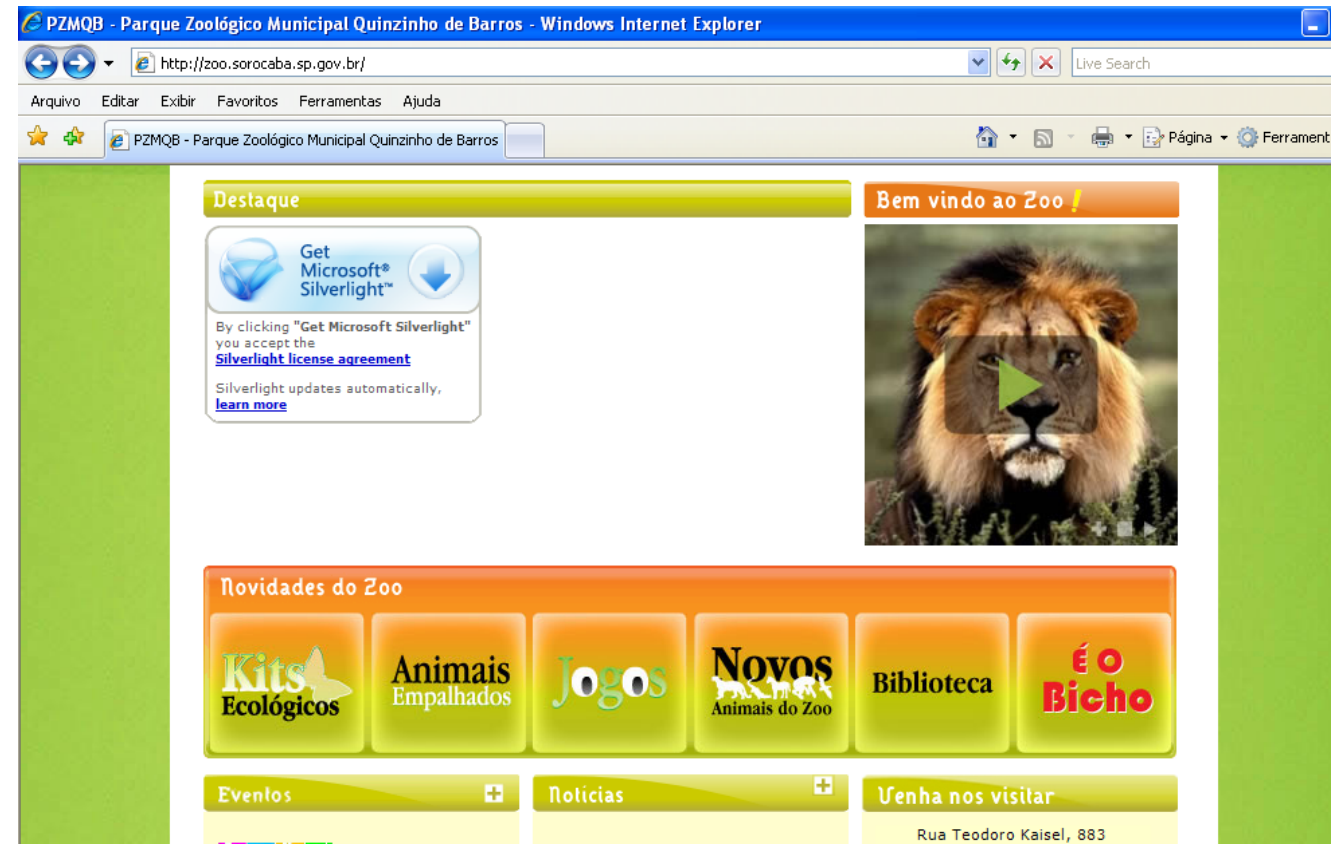

Figura 1 - Site do Zoológico de Sorocaba

\section{Centro de Documentação do Zoológico de Belo Horizonte}

O assistente administrativo Délcio Veríssimo, atual responsável pelo mesmo, informou que o Centro de Documentação é precário, não o considerando como uma biblioteca, pois para ele a maior função do Centro de Documentação é de ser depositário das informações referentes ao Zoológico. Não conta com bibliotecários em seu quadro de funcionários. Segundo ele, o Centro de Documentação é mais utilizado por estudantes, caracterizando-se mais como uma Biblioteca Escolar.

Para a Biblioteca do Jardim Zoológico de Lisboa foi enviado um e-mail como primeiro contato, solicitando informações sobre a Biblioteca e sobre bibliografias existentes em biblioteca especializada em Zoológicos. Como resposta a senhora Patrícia Caldas enviou um e-mail onde afirma que a consulta interna é o principal objetivo da biblioteca, ou seja, ela está voltada 
aos funcionários e colaboradores do Zoológico, porém disponibiliza para o público externo a consulta local ao acervo.

As Bibliotecas Especializadas devem conter informações que supram as necessidades de seus funcionários e colaboradores bem como de seus frequentadores. Contudo, para gerenciar essas informações elas necessitam de funcionários qualificados, o que não foi encontrado em nenhuma das bibliotecas pesquisadas. 


\section{Estudo de Caso: A Biblioteca do Jardim Zoológico de Brasília, DF}

De acordo com Godoy (1995 apud VOLPATO, 2000, p. 91) “o propósito fundamental de um estudo de caso é analisar profundamente e com detalhes uma determinada unidade social, procurando retratar a multiplicidade de dimensões que a compõem, sempre buscando contextualizar o que se escolheu focalizar com a pesquisa".

Ao analisar o contexto no qual a Biblioteca do Zoológico está inserida, será possível constatar a importância da mesma no ambiente não só cultural e de lazer dos brasilienses, mas também para estudo de pesquisadores, funcionários e estudantes.

\subsection{Distrito Federal - DF}

O sonho de Dom Bosco foi um dos marcos, quando se começou a pensar na construção de Brasília. Neste sonho, de acordo o site do Governo do Distrito Federal (www.distritofederal.df.gov.br, 29/04/09) "Dom Bosco vislumbrou uma depressão bastante larga e comprida, partindo de um ponto onde se formava um grande lago, entre os paralelos $15^{\circ}$ e $20^{\circ}$, e que repetidamente uma voz lhe dizia que '... quando vierem escavar as minas ocultas, no meio destas montanhas, surgirá aqui a terra prometida, vertendo leite e mel. Será uma riqueza inconcebível...".

Brasília tem suas origens muito antes do início da construção da capital. Muitos, dentre eles Marques de Pombal e os Inconfidentes Mineiros tiveram a idéia de transferir a sede do governo, sendo tais fatos ocorridos na segunda metade do século XVIII. Segundo o mesmo site: "Depois da independência, na sessão da Assembléia Geral Constituinte do Império de 7 de junho de 1823, o deputado Antônio Ferreira França leu memorial de José Bonifácio de Andrada e Silva, onde este propunha a instalação da capital na recém-criada comarca de Paracatu do Príncipe. O nome seria Brasília ou Petrópole”. A partir de 1839, passou-se a imaginar a construção de uma cidade no Planalto Central, sendo que foi com a Constituição de 1891 que se estabeleceu à mudança da Capital, 
fato esse confirmado pela Constituição de 1934. Tal acontecimento provocou a divergência de opiniões quanto ao local da nova capital. A Constituição de 18 de setembro de 1946 determinou que a capital fosse transferida para o Planalto Central. Juscelino Kubitschek em sua campanha eleitoral, quando questionado sobre a mudança da capital, afirmou que cumpriria a Constituição Federal.

A assinatura da Mensagem de Anápolis por Juscelino, posteriormente transformada na lei $n^{\circ} 2.874$, de 19 de setembro de 1956, oficializou o nome Brasília para a futura capital e lançou as bases da Companhia Urbanizadora da Nova Capital - Novacap. Com isso, em 21 de abril de 1960, Brasília foi inaugurada, pelo então presidente Juscelino Kubitschek. Em 1987, a Comissão de Sistematização da Assembléia Nacional Constituinte aprovou a autonomia política do Distrito Federal, no mesmo ano, Brasília foi declarada pela UNESCO, Patrimônio Histórico e Cultural da Humanidade.

Atualmente, o Distrito Federal se tornou o principal cenário da política nacional como já previa Juscelino "Deste planalto central, desta solidão que em breve se transformará em cérebro das altas decisões nacionais, lanço os olhos mais uma vez sobre o amanhã do meu país e antevejo esta alvorada com fé inquebrantável e uma confiança sem limites no seu grande destino" (www.distritofederal.df.gov.br, 29/04/09). É a cidade com um dos maiores Índice de Desenvolvimento Humano - IDH do Brasil e representa cerca de $90 \%$ do Produto Interno Bruto - PIB, com forte presença na área administrativa, de prestação de serviços e comércio.

Conta com cerca de 2.455.903 (2008) habitantes, divididos entre, mais ou menos vinte e seis Regiões Administrativas - RA's, sendo elas: Planaltina, Candangolândia, Núcleo Bandeirante, Taguatinga, Cruzeiro, Brazlândia, Brasília, Sobradinho, Gama, Guará, Ceilândia, Samambaia, Paranoá, Santa Maria, Riacho Fundo, São Sebastião, Recanto das Emas, Lago Norte e Lago Sul, Águas Claras, Varjão, Sudoestel Octogonal, Park Way, Setor Complementar de Indústrias e Abastecimento, Sobradinho II, Jardim Botânico, Itapoã. 


\subsubsection{Dados Demográficos, Econômicos e Sociais}

O Distrito Federal apresenta a maior renda per capita do Brasil, o desemprego atinge menos da metade da população economicamente ativa do DF, porém a desigualdade social é uma das mais estáveis do Brasil.

Possui uma das densidades demográficas mais altas do país, contudo o risco de explosão populacional está afastado, de acordo (http://www.portalbrasil.net/estados_df.htm, 11/05/09).

Do ponto de vista econômico e social, são apresentados os dados, segundo o site do Distrito Federal (www.distritofederal.df.gov.br, 29/04/09).

Na Figura 2, estão os dados demográficos, climáticos e situacionais:

\begin{tabular}{|l|l|}
\hline \multicolumn{2}{|c|}{ INDICADORES DEMOGRÁFICOS E SOCIAIS } \\
\hline Area: & $5.789,16 \mathrm{Km}^{2}$ \\
\hline Densidade: & $354,3 \mathrm{hab} . / \mathrm{km}^{2}$ \\
\hline Altitude: & $1.172 \mathrm{~m}$ \\
\hline Clima: & $\begin{array}{l}\text { Tropical de Savana e Temperado Chuvoso de } \\
\text { Inverno Seco }\end{array}$ \\
\hline Temperatura Média Anual: & $20,5^{\circ}$ \\
\hline Umidade Relativa do Ar: & 40 a $70 \%$ \\
\hline Código DD/Fax: & 61 \\
\hline Voltagem: & $220 \mathrm{~V}$ \\
\hline Hora Local: & $-3 \mathrm{~h}$ em relação ao Meridiano de Greenwich \\
\hline População: & 2.455 .903 hab \\
\hline Fonte: wmw.distritofederal.df.gov.br & \\
\hline
\end{tabular}

Figura 2 - Indicadores demográficos e sociais do DF

Do ponto de vista econômico, as principais riquezas do DF, conforme Figura 3 são:

\begin{tabular}{|l|l|}
\multicolumn{2}{|c|}{ INDICADORES ECONÔMICOS } \\
\hline Participação no PIB (\%) & 1,8 \\
\hline Produtos agrícolas & $\begin{array}{l}\text { Café, Goiaba, Laranja, Limão, Mamão, Manga e } \\
\text { Tangirina }\end{array}$ \\
\hline Produtos minerais & Água Mineral, Calcário e Dolomita \\
\hline Pecuária - bovinos (cabeças) & 110.157 \\
\hline Extrativismo vegetal & Madeiras \\
\hline Indústria & Construção civil, gráfica, de transformação. \\
\hline $\begin{array}{l}\text { Arrecadação de ICMS 2002 - Valor } \\
\text { Provisório (R\$) }\end{array}$ & $1.804 .582,00$ \\
\hline Fonte: www.distritofederal.df.gov.br & \\
\hline
\end{tabular}

Figura 3 - Indicadores econômicos do DF 
$\mathrm{Na}$ Figura 4, encontram-se os dados relacionados aos aspectos gerais e sócio-econômicos do DF:

DADOS SÓCIO-ECONÔMICOS

\begin{tabular}{|l|l|}
\hline Área $\left(\mathrm{Km}^{2}\right)$ & $5.789,16$ \\
\hline Densidade (hab./km²) & 354,3 \\
\hline Crescimento Demográfico (\% ao ano) & 2,82 \\
\hline Vegetação & Cerrado \\
\hline Rios principais & $\begin{array}{l}\text { Paranoá, Preto, Santo Antônio do Descoberto, } \\
\text { São Bartolomeu }\end{array}$ \\
\hline Clima & Tropical \\
\hline $\begin{array}{l}\text { Índice de Desenvolvimento Humano - IDH (0- } \\
\text { 1) }\end{array}$ & 0,844 \\
\hline Analfabetismo (\%) & 4,35 \\
\hline Eleitores & 1.518 .437 \\
\hline
\end{tabular}

Fonte: www.distritofederal.df.gov.br

Figura 4 - Dados sócio-econômicos do DF

Com relação a Densidade Demográfica (hab/km²), a Figura 5 apresenta os dados por Região Administrativa:

\begin{tabular}{|c|c|c|c|}
\hline $\begin{array}{c}\text { Regiões } \\
\text { Administrativas }\end{array}$ & $\begin{array}{l}\text { Área total } \\
\left(\mathrm{km}^{2}\right)\end{array}$ & População* & $\begin{array}{c}\text { Densidade Demográfica } \\
\left(\mathrm{hab} / \mathrm{km}^{2}\right)\end{array}$ \\
\hline RA 1 Brasília & $\begin{array}{l}472,12 \\
(8,1 \%)\end{array}$ & $\begin{array}{l}198.422 \\
(9,6 \%)\end{array}$ & 420 \\
\hline RA 2 Gama & $\begin{array}{l}276,34 \\
(4,7 \%)\end{array}$ & $\begin{array}{c}130.580 \\
(6,3 \%)\end{array}$ & 472,5 \\
\hline RA 3 Taguatinga & $121,55(2 \%)$ & $\begin{array}{l}243.575 \\
(11,8 \%) \\
\end{array}$ & $2.003,9$ \\
\hline RA 4 Brazlândia & $\begin{array}{l}474,83 \\
(8,2 \%)\end{array}$ & $52.698(2,5 \%)$ & 110,9 \\
\hline RA 5 Sobradinho & $\begin{array}{l}572,59 \\
(9,8 \%)\end{array}$ & $\begin{array}{l}128.789 \\
(6,2 \%)\end{array}$ & 224,9 \\
\hline RA 6 Planaltina & $\begin{array}{l}1.534,69 \\
(26,5 \%) \\
\end{array}$ & $\begin{array}{c}147.114 \\
(7,1 \%)\end{array}$ & 95,8 \\
\hline RA 7 Paranoá & $\begin{array}{r}853,33 \\
(14,7 \%)\end{array}$ & $54.902(2,6 \%)$ & 64,3 \\
\hline $\begin{array}{l}\text { RA } 8 \text { Núcleo } \\
\text { Bandeirante }\end{array}$ & $80,43(1,3 \%)$ & $36.472(1,7 \%)$ & 453,4 \\
\hline RA 9 Ceilândia & $\begin{array}{l}230,33 \\
(3,9 \%) \\
\end{array}$ & $\begin{array}{l}344.039 \\
(16,7 \%)\end{array}$ & $1.493,6$ \\
\hline RA 10 Guará & $45,46(0,7 \%)$ & $\begin{array}{l}115.385 \\
(5,6 \%)\end{array}$ & $2.538,1$ \\
\hline RA 11 Cruzeiro & $8,9(0,15 \%)$ & $63.883(3,1 \%)$ & $7.177,8$ \\
\hline RA 12 Samambaia & $105,7(1,8 \%)$ & $\begin{array}{l}164.319 \\
(8,0 \%)\end{array}$ & $1.554,5$ \\
\hline RA 13 Santa Maria & 215,86 & $98.679(4,8 \%)$ & 457,1 \\
\hline
\end{tabular}




\begin{tabular}{|c|c|c|c|}
\hline & $(3,7 \%)$ & & \\
\hline $\begin{array}{l}\text { RA } 14 \text { São } \\
\text { Sebastião }\end{array}$ & $\begin{array}{l}383,71 \\
(6,6 \%)\end{array}$ & $64.322(3,1 \%)$ & 167,6 \\
\hline $\begin{array}{c}\text { RA } 15 \text { Recanto das } \\
\text { Emas }\end{array}$ & $\begin{array}{l}101,22 \\
(1,7 \%) \\
\end{array}$ & $93.287(4,5 \%)$ & 921,6 \\
\hline RA 16 Lago Sul & $\begin{array}{l}183,39 \\
(3,1 \%)\end{array}$ & $28.137(1,3 \%)$ & 153,4 \\
\hline $\begin{array}{l}\text { RA } 17 \text { Riacho } \\
\text { Fundo }\end{array}$ & $56,02(0,9 \%)$ & $41.404(2,0 \%)$ & 739 \\
\hline RA 18 Lago Norte & $66,08(1,1 \%)$ & $29.505(1,4 \%)$ & 446,5 \\
\hline $\begin{array}{c}\text { RA } 19 \\
\text { Candangolândia }\end{array}$ & $6,61(0,1 \%)$ & $15.634(0,7 \%)$ & $2.365,2$ \\
\hline Distrito Federal & $\begin{array}{c}5.789,16 \\
(100 \%)\end{array}$ & $\begin{array}{c}2.051 .146 \\
(100 \%)\end{array}$ & 354,3 \\
\hline \multicolumn{4}{|l|}{ Fontes: } \\
\hline \multicolumn{4}{|c|}{ - Companhia Energética de Brasília - CEB } \\
\hline \multicolumn{4}{|c|}{ - Conselho Nacional de Política Fazendária - CONFAZ } \\
\hline \multicolumn{4}{|c|}{ - Instituto Brasileiro de Geografia e Estatística - IBGE } \\
\hline
\end{tabular}

Figura 5 - Regiões Administrativas do DF por densidade demográfica

\subsection{Governo do Distrito Federal - GDF}

O Governo do Distrito Federal teve início com a criação de Brasília, que determinou que o DF seria uma região distinta de Goiás. Brasília tornou-se a sede do Governo Federal e do Distrito Federal, na década de 1960. O primeiro representante político do Distrito Federal foi Israel Pinheiro, engenheiro presidente da Novacap nomeado prefeito de Brasília pelo Presidente da República, em 17 de abril de 1960. Além de Israel outros representaram Brasília na condição de Prefeito entre eles: Paulo de Tarso, José câmara, Ivo de Magalhães, Ivan de Souza, Plínio Cantanhede, Wadjô Gomide, Hélio Prates, Elmo Faria, Aimé Lamaison, José Ornellas, Ronaldo Couto e José de Oliveira.

Até 1988, todos os governantes de Brasília foram indicados e nomeados pelo Presidente da República. A Constituição de 1988 estabeleceu, no artigo 32, eleições diretas para Governador, Vice-Governador e 24 Deputados Distritais: que "tiveram como primeira atribuição à elaboração da Lei Orgânica do Distrito Federal - LODF de 09 de junho de 1993".(www.distritofederal.df.gov.br, 04/05/09).

Como governadores eleitos o DF teve: Joaquim Roriz (1988/1990; 1991/1995; 1999/2006), Wanderley Silva (de 1990 a 1991), Cristovam Buarque (1995/1999), Maria de Lourdes Abadia (2006) e José Roberto Arruda (atual). 
O Governo do Distrito Federal, atualmente, é composto de 21 Secretarias, sendo uma delas a responsável pelo desenvolvimento urbano e do meio ambiente, como mostra a Figura 6.

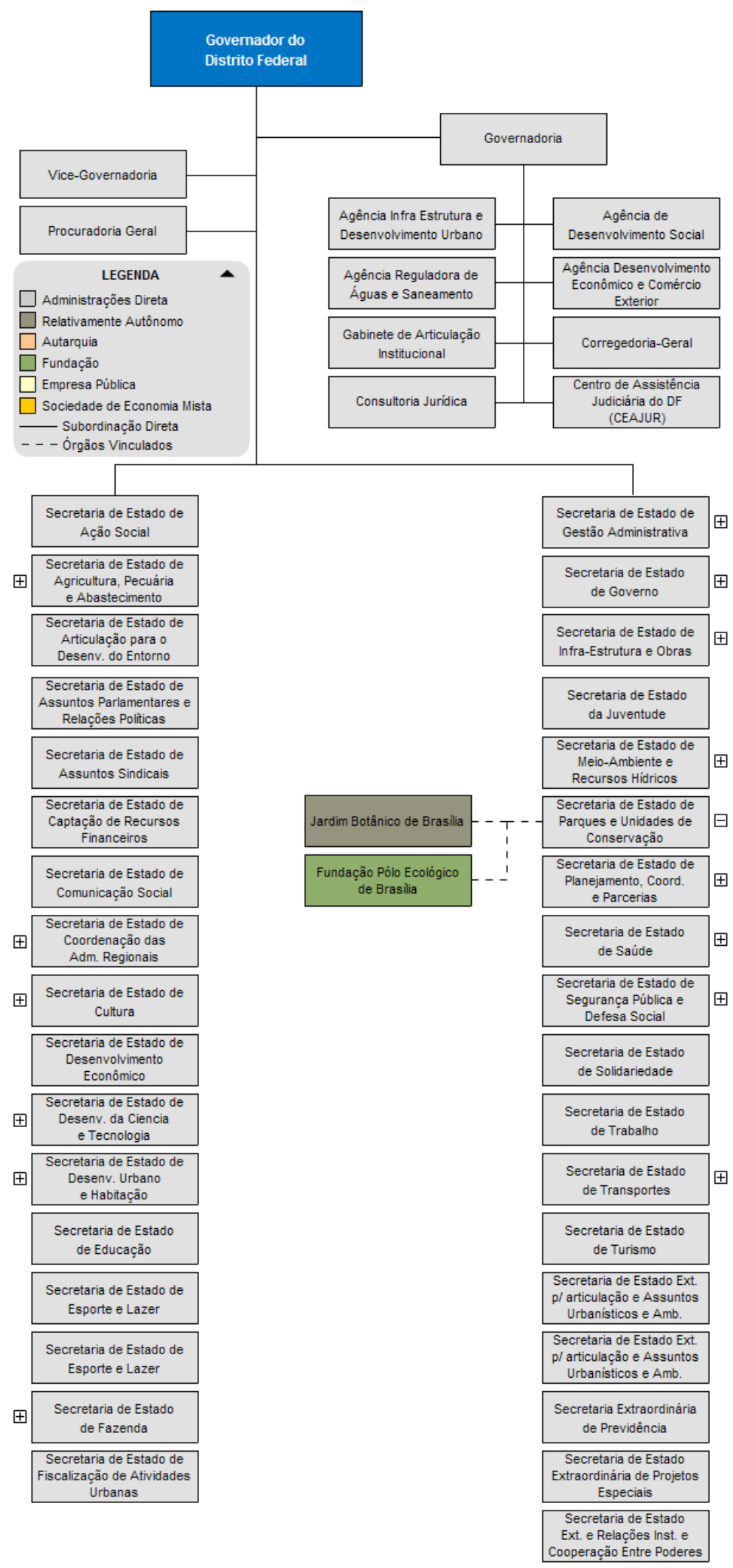

Figura 6 - Organograma do GDF 


\subsection{Secretaria de Desenvolvimento Urbano e Meio Ambiente - SEDUMA}

A SEDUMA foi criada em 2007 com o Decreto $n^{0} 27.591$ de $1^{\circ}$ janeiro de 2007, que dispõe sobre a estruturação administrativa do GDF, declarando extinta a Secretaria de Estado de Administração de Parques e Unidades de Conservação do Distrito Federal - COMPARQUES criando a Secretaria de Estado de Desenvolvimento Urbano e Meio Ambiente - SEDUMA, como parte da estrutura de administração do Distrito Federal, como órgão da administração direta do GDF.

A Secretaria de Estado de Desenvolvimento Urbano e Meio Ambiente do Distrito Federal - SEDUMA é a Secretaria responsável entre outros por administrar os parques do DF, inclusive o Jardim Zoológico de Brasília. A SEDUMA, segundo o site do Governo do Distrito Federal: "atua em operações de retirada de ocupantes irregulares nos Parques e Unidades de Conservação de sua competência. Nesses locais, o órgão também presta serviços nas seguintes áreas: hidráulica, elétrica, serralheria, marcenaria, plantio, cercamento, calçamento e pavimentação".

De acordo com o organograma da SEDUMA, apresentado na Figura 7, pode-se verificar a sua estrutura administrativa: 


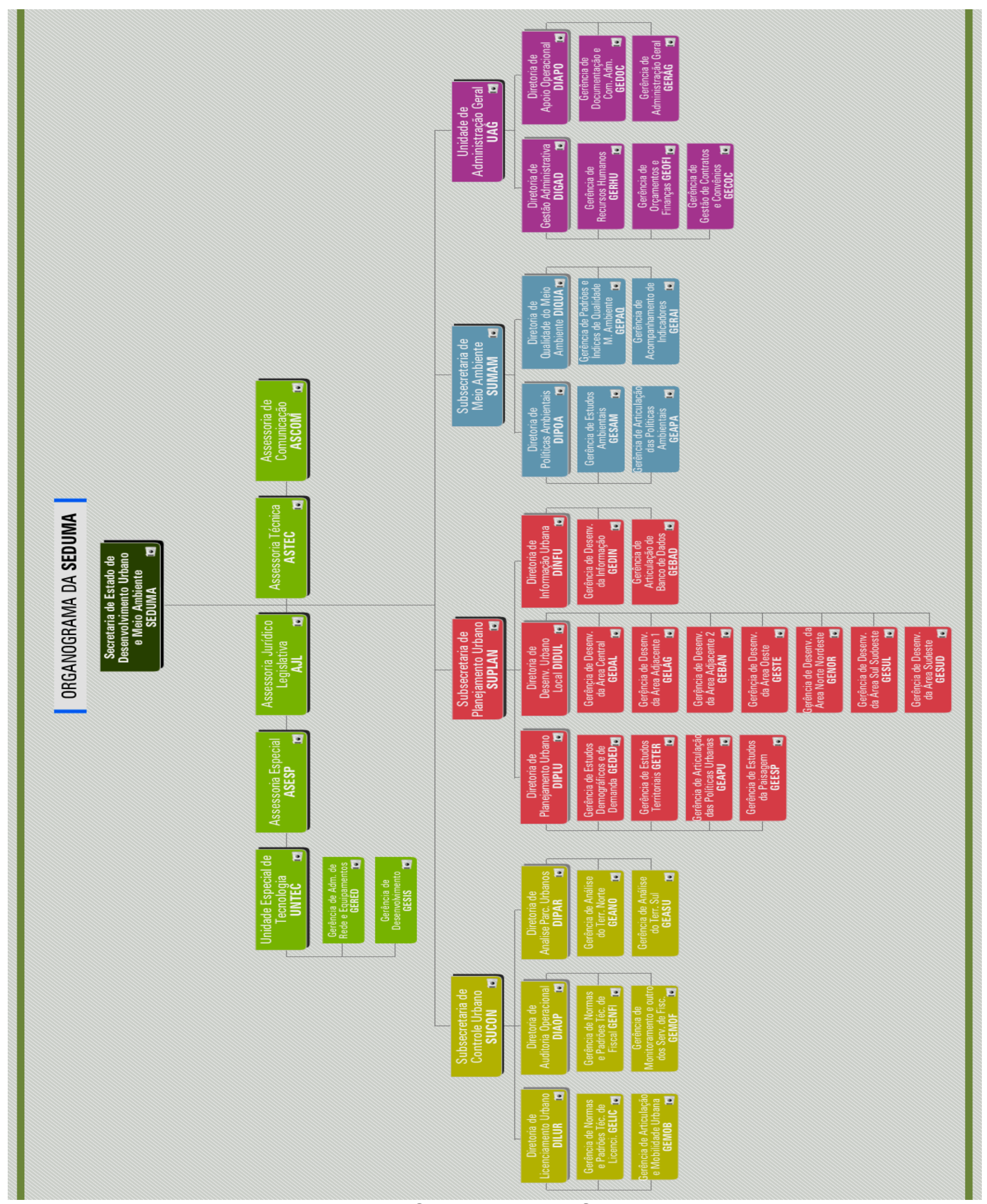

Figura 7- Organograma da SEDUMA 
A Secretaria conta também com serviços de mão-de-obra especializada e parcerias com órgãos públicos como Caesb, Novacap, Belacap, CPMA, Terracap, Jardim Botânico de Brasília, Jardim Zoológico de Brasília, Serviço de Limpeza Urbana do DF - SLU, Agência Reguladora de Águas e Saneamento do Distrito Federal - ADASA, Instituto Brasília Ambiental - Ibram.

O governador José Roberto Arruda nomeou, em 2007, o engenheiro Cassio Taniguchi para assumir o cargo de Secretário de Desenvolvimento Urbano e Meio Ambiente do Distrito Federal.

\subsection{Fundação Jardim Zoológico de Brasília - ZOO}

A Fundação Jardim Zoológico de Brasília (ZOO) está vinculada a Seduma, como um órgão da administração indireta do GDF. Foi instituída pelo Decreto $\mathrm{n}^{\circ} 27.591$ de $1^{\circ}$ de janeiro de 2007. É constituída pelo Jardim Zoológico de Brasília, o Santuário da Vida Silvestre do Riacho Fundo e pelo Parque das Aves. Possui como objetivo a conservação, a pesquisa das espécies, da fauna, bem como a educação e o lazer.

Conforme o site www.zoo.df.gov.br, 04/05/09:

O Zoológico não é apenas lugar de visitação. A intenção é a preservação das espécies, reprodução, pesquisa e educação ambiental. Contamos ainda com lanchonetes, teatro de arena, auditório e o museu de taxidermia.

O Zoológico foi a primeira instituição ambientalista criada no Distrito Federal.

O Zoológico foi inaugurado no dia 6 de dezembro de 1957, por Juscelino Kubitschek, antes mesmo do término da construção de Brasília. Grande parte de sua historia é simbolizada pela elefanta Nely que foi o primeiro animal a fazer parte do Parque Ecológico. Ela foi doada por um fazendeiro goiano para presentear o então presidente JK. Porém, morreu em 1994 devido ao grande desgaste que sofreu quando era atração de circo.

Hoje, o Zoológico conta com uma área de 148 hectares que, somadas às áreas do Santuário da Vida Silvestre do Riacho Fundo e do Parque das Aves, totalizam mais de 690 hectares, onde se encontram aproximadamente 1200 animais entre aves, répteis e mamíferos, num total de 300 espécies, 193 da 
fauna brasileira e 107 da fauna exótica, distribuídas de acordo com o Plano Diretor, e divididos por continentes: América, Ásia. África, Europa e Oceania. A média de visitantes ao Zoológico é de 700.000 mil pessoas por ano.

A Fundação Jardim Zoológico de Brasília é mantida pelo Governo do Distrito Federal. O Zoológico não tem autonomia sob seus recursos financeiros, o que faz com que o mesmo dependa da aprovação dos superiores hierárquicos para qualquer benfeitoria a ser realizada nas dependências do Zoológico.

Em seu quadro de funcionários, o Zoológico possui 210 funcionários, sendo 41 funcionários do quadro (servidores) e 169 distribuídos entre terceirizados (serviço de limpeza, segurança, trabalho de campo), comissionados, estagiários e pesquisadores. Atualmente, o Zoológico funciona com servidores concursados na década de 1980, tornando urgente a necessidade de reciclagem e renovação da sua força de trabalho.

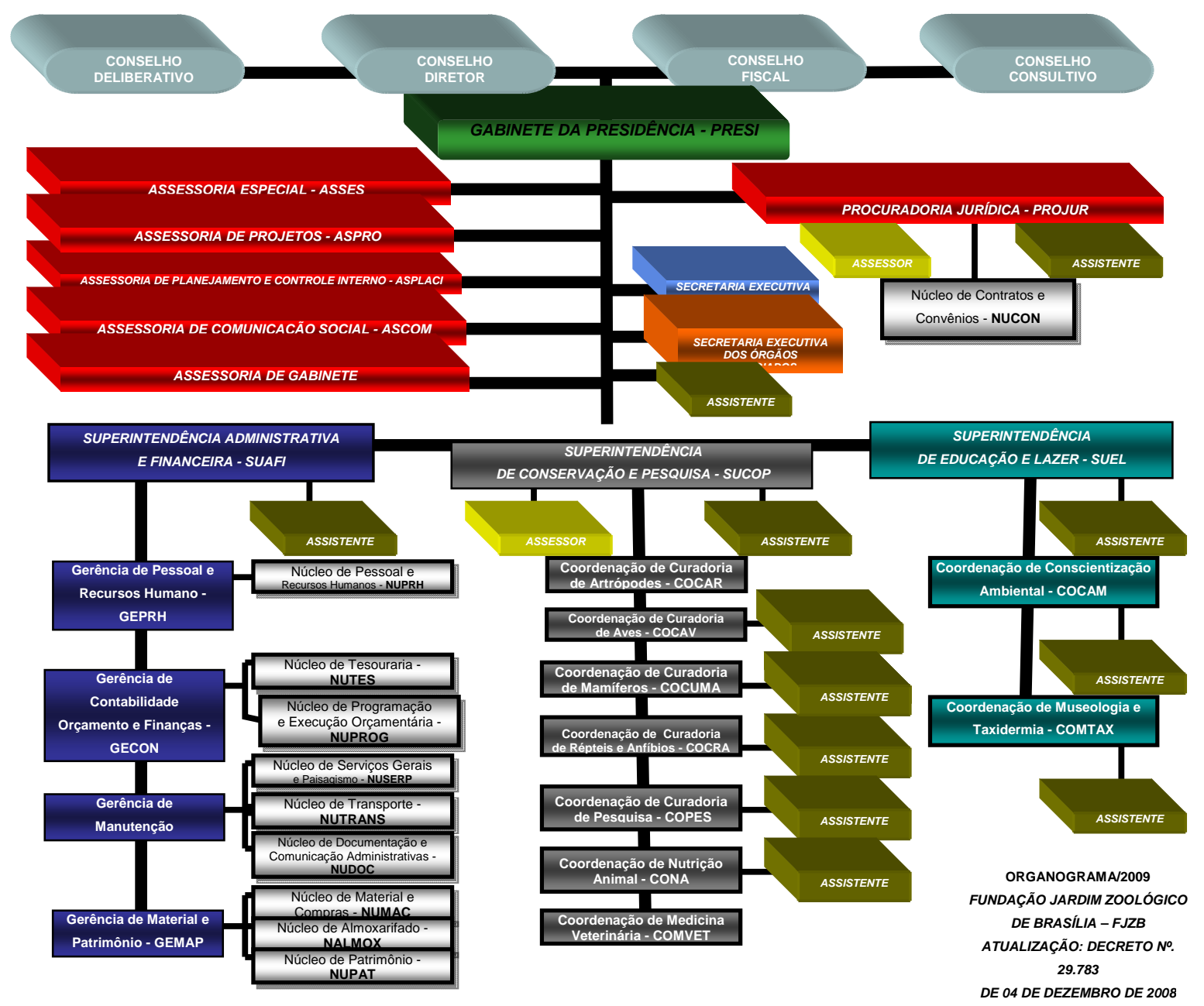

Figura 8 - Estrutura hierárquica do Zoológico de Brasília 


\subsection{Biblioteca do Jardim Zoológico de Brasília - BEZOO}

O Jardim Zoológico possuía uma biblioteca localizada no Parque das Aves, em frente ao Zoológico, porém devido a um incêndio em 3 de julho de 2007, a biblioteca foi totalmente destruída, não se sabe se acidentalmente ou criminosamente. Toda a história, documentos, fotos e relatos foram queimados no incêndio, restando apenas poucas folhas do que um dia fora um acervo inteiro sobre a sua história e dos animais do Zoológico, todo o acervo foi reduzido a cinzas.

Atendia, principalmente, os estudantes de nível fundamental e os funcionários da instituição. Contava com uma funcionária, sem formação na área de biblioteconomia, que administrava e organizava o ambiente. Era dotada de um acervo pequeno, mas era bastante freqüentada e utilizada.

Foi realizada uma entrevista com a funcionária Núbia Feitosa Braga Lourenço que era responsável pelo funcionamento da Biblioteca. Ela trabalhou por nove anos nessa unidade. É formada em Pedagogia e Teologia, não tendo, porém feito curso de auxiliar de biblioteca ou similar. Segundo Núbia, o acervo possuía menos de 1000 títulos, em sua maioria de Biologia, Literatura e alguns de Direito, que eram organizados por assunto. O acervo não era informatizado e havia um computador para toda a biblioteca.

Seus usuários eram estudantes de ensino fundamental e médio que visitavam o Zoológico, e com regular freqüência à Biblioteca.

A biblioteca realizava empréstimos apenas para fotocópia, onde o interessado deixava um documento na Referência como garantia e retirava o livro ou periódico por algumas horas. Possuía também um espaço para crianças, onde às vezes era realizada a leitura de histórias infantis.

Segundo Núbia, havia falta de divulgação da biblioteca, bem como a necessidade de dinamização de suas atividades: "A biblioteca deixou de ser um lugar de pesquisa para ser somente depositária da história do Zoológico".

No segundo semestre de 2007, a Fundação Jardim Zoológico de Brasília decidiu construir uma unidade de informação para o Zoológico.

O Zoológico por não possuir orçamento para a construção da biblioteca, optou por solicitar ajuda às estudantes de Biblioteconomia da Universidade de Brasília, Deise Lourenço, Gabriele Lopes e Mônica dos Reis, (sendo, as duas últimas, autoras desta monografia) que prontamente se dispuseram a ajudar 
por meio da realização de um Projeto Executivo da Biblioteca do Jardim Zoológico de Brasília, orientado pela professora Maria Alice Guimarães Borges.

O documento é composto, inicialmente, de 2 partes: Diagnóstico e Projeto de Implementação. O projeto foi estruturado em 5 módulos, que se constituem nas fases do seu desenvolvimento: instalações físicas, estrutura organizacional, coleta, processos técnicos, disseminação e atendimento ao usuário.

No Módulo 1 - Instalações Físicas foi concretizada a etapa de elaboração do Programa da Biblioteca para planejamento do projeto arquitetônico, que foi devidamente entregue a Direção do Jardim Zoológico, para execução das demais etapas.

Esta monografia corresponde ao Módulo 5 - Disseminação e Atendimento ao Usuário. Ele inclui a definição dos produtos e serviços a serem oferecidos aos usuários, leva em consideração a caracterização e relevância das necessidades dos usuários potenciais da biblioteca. Por meio desses dados, é elaborada uma proposta de serviços de informação a serem oferecidos pela Biblioteca do Zoológico.

\begin{tabular}{|l|l|l|l|}
\hline $\begin{array}{c}N^{0} \\
\text { ordem }\end{array}$ & \multicolumn{1}{|c|}{ Módulos } & \multicolumn{1}{|c|}{ Etapas } & \multicolumn{1}{c|}{ Atividades } \\
\hline 1 & Instalações físicas & $\begin{array}{l}\text {-Programa da Biblioteca para } \\
\text { elaboração do projeto; } \\
\text { - Projeto da estrutura Física; } \\
\text { - Detalhamento do mobiliário e e } \\
\text { equipamentos; } \\
\text { - Construção. }\end{array}$ & $\begin{array}{l}\text { - Reuniões e discussões. } \\
\text { - Pesquisas de equipamentos e } \\
\text { preços. }\end{array}$ \\
\hline 2 & Estrutura organizacional & $\begin{array}{l}\text { - Definição da estrutura } \\
\text { organizacional; } \\
\text { - Seleção de pessoal; } \\
\text { - Contratação de pessoal; }\end{array}$ & $\begin{array}{l}\text { - Reuniões e discussões para } \\
\text { estabelecer a estrutura } \\
\text { organizacional; }\end{array}$ \\
\hline 3 & - Seleção. & $\begin{array}{l}\text { - Estabelecimento da política de } \\
\text { seleção do acervo; } \\
\text { - Obtenção de verbas; } \\
\text { - Levantamento de doadores; } \\
\text { - Campanha de doação; } \\
\text { - Levantamento de bibliotecas } \\
\text { especializadas em Zoológicos. }\end{array}$ \\
\hline 4 & Processos Técnicos & $\begin{array}{l}\text { - Aquisição. } \\
\text { - Doação. } \\
\text { - Intercâmbio. }\end{array}$ & $\begin{array}{l}\text { - Escolha de softwares, códigos e } \\
\text { formatos para trabalho; } \\
\text { - Escolha da classificação; } \\
\text { - Escolha do Tesauro ou } \\
\text { Vocabulário Controlado para } \\
\text { indexação. }\end{array}$ \\
\hline
\end{tabular}




\begin{tabular}{|l|l|l|l|}
\hline 5 & $\begin{array}{l}\text { Disseminação e } \\
\text { Atendimento ao usuário. }\end{array}$ & - Empréstimo; & $\begin{array}{l}\text { - Elaboração das regras para } \\
\text { empréstimo; } \\
\text { - Definição dos padrões de } \\
\text { atendimento ao usuário; } \\
\text { - Definição dos produtos e } \\
\text { serviços a serem oferecidos aos } \\
\text { usuários; }\end{array}$ \\
\hline
\end{tabular}

Fonte: Projeto de Implementação da Biblioteca do Zoológico de Brasília

Figura 9 - Quadro de atividades do projeto

\subsection{Necessidades de informação dos usuários do ZOO - Análise dos dados}

Para o levantamento das necessidades de informação dos usuários da Biblioteca do Zoológico foram realizados dois levantamentos: dos seus frequentadores e dos funcionários e colaboradores.

\subsubsection{Frequentadores}

Para o levantamento dos frequentadores foi elaborado um questionário com oito questões fechadas e uma aberta. Foram aplicados 100 questionários, no período de duas semanas. A partir da análise dos questionários foi possível estabelecer o perfil dos mesmos, bem como a importância dada à existência da Biblioteca, conforme gráficos e análise apresentados a seguir.

\section{Idade dos entrevistados}

A Figura 10 mostra que $44 \%$ dos entrevistados têm idades entre 21 e 25 anos, $13 \%$ estão entre 26 e 30 , sendo que $5 \%$ têm menos de 16 anos, ou seja, a maioria dos entrevistados são pessoas adultas. A média de idade é de 28,29 anos.

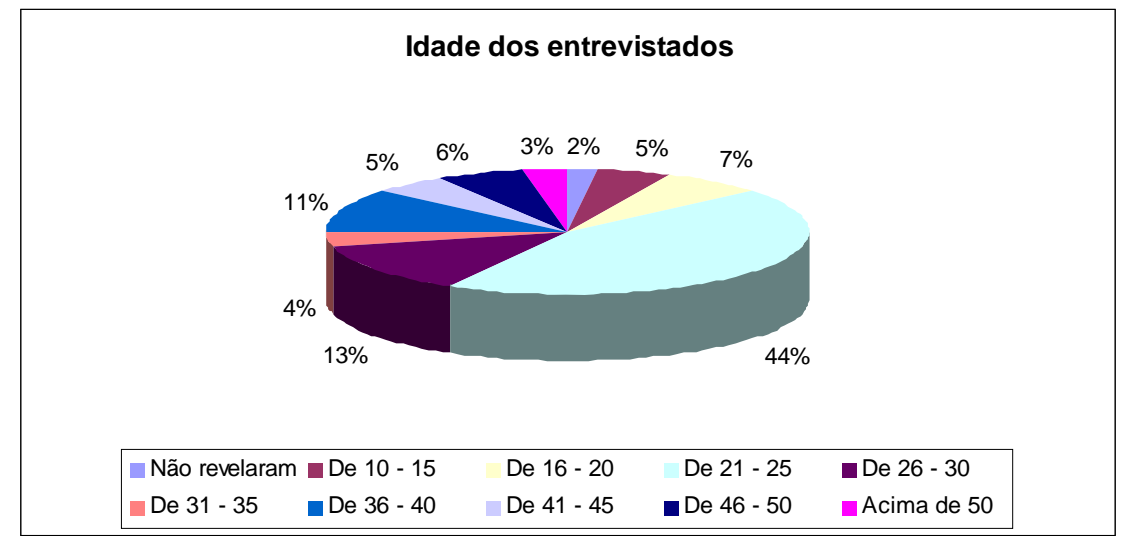

Figura 10 - Idade dos frequentadores entrevistados 


\section{Nível de instrução}

Pela observação da Figura 11, 44\% dos entrevistados estão cursando 0 nível superior, $20 \%$ já o concluíram e 9\% têm pós-graduação, mestrado ou doutorado. Porém 31\% estudaram até o ensino médio, o que nos mostra que o público adulto e adolescente do Zoológico tem níveis variados de escolaridade. Logo, a Biblioteca deve conter documentos diversos na área a que se destina, capazes de atender às necessidades informacionais dos diferentes usuários que freqüentam o Zoológico. Deve ser observado que grande parte de seus frequentadores são crianças, portanto, estão em fase escolar. Importante notar também que nenhum entrevistado declarou que não sabe ler.

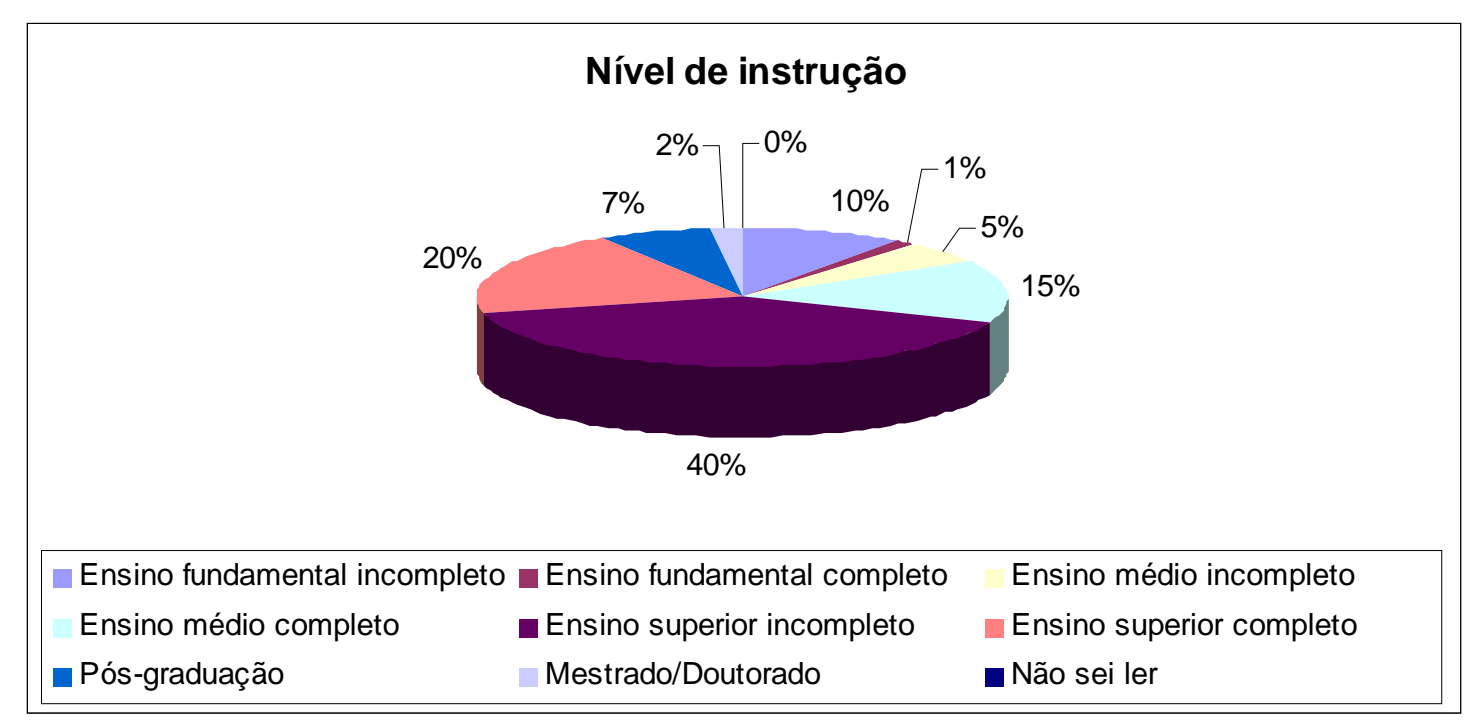

Figura 11 - Nível de instrução dos frequentadores

\section{Dias de frequência ao ZOO}

A figura 12 mostra que a grande maioria dos entrevistados (82\%) costuma ir ao Zoológico aos fins de semana, e somente 7\% durante a semana. Os $11 \%$ que não se aplicam a estas duas opções se deve ao fato de que estavam visitando o ZOO pela primeira vez, no dia da pesquisa. 


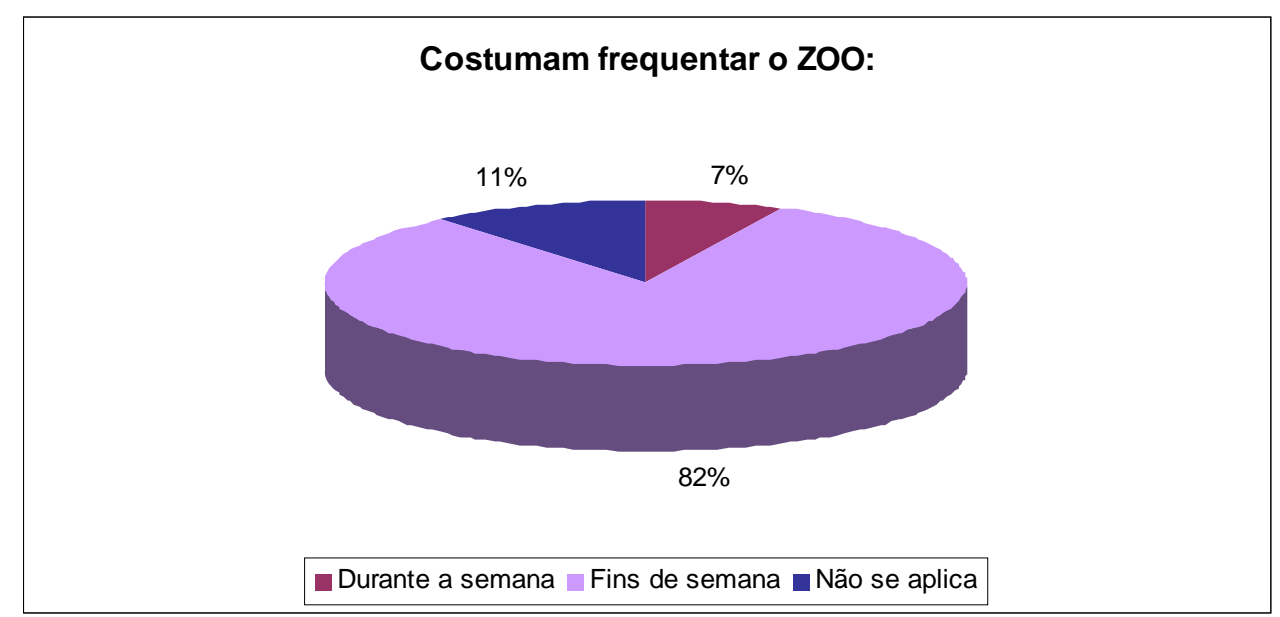

Figura 12 - Dias de frequência ao ZOO.

\section{Criação da Biblioteca}

Como mostra a Figura $13,70 \%$ dos entrevistados disseram que freqüentariam a Biblioteca do Zoológico, 20\% colocou que seria uma boa idéia a construção de uma Biblioteca no ZOO, mas não a frequentariam por se localizar distante de suas residências ou trabalho. Por outro lado, 10\% afirmaram ser desnecessária, pois para eles os visitantes não se interessam em ler livros no ZOO, ou consideram de difícil acesso para fazer empréstimo de livros.

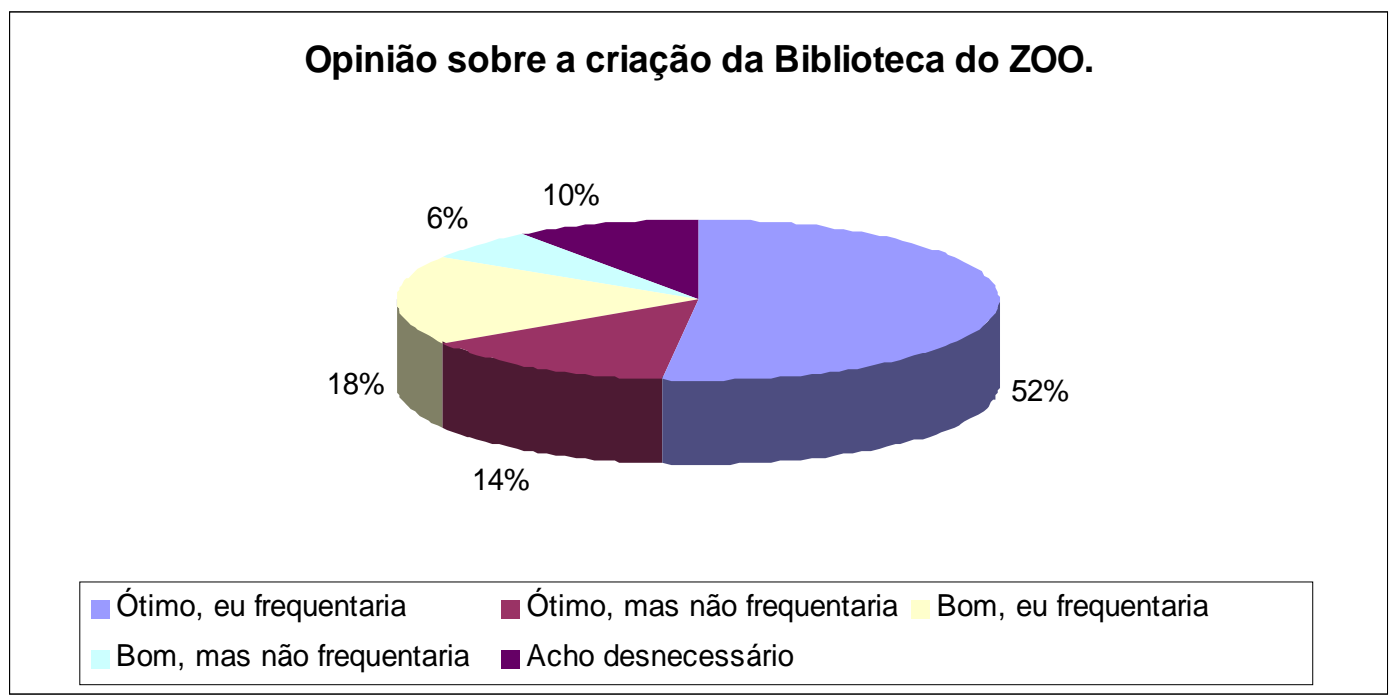

Figura 13 - Criação da Biblioteca do ZOO. 


\section{Assuntos de interesse}

Os assuntos que interessam a maior parte dos entrevistados são 'preservação ambiental', 'educação ambiental' e 'literatura infantil'. 'Veterinária' e 'botânica' foram os de menor interesse, conforme a Figura 14.

Observa-se que pelo menos um assunto foi marcado em todos os questionários. Na opção Outros do questionário, os assuntos sugeridos foram: Religião, Literatura, Material para concursos, Línguas, entre outros.

Diante destes dados é possível estabelecer os grandes assuntos que deverão fazer parte do acervo da Biblioteca, independente do seu suporte físico.

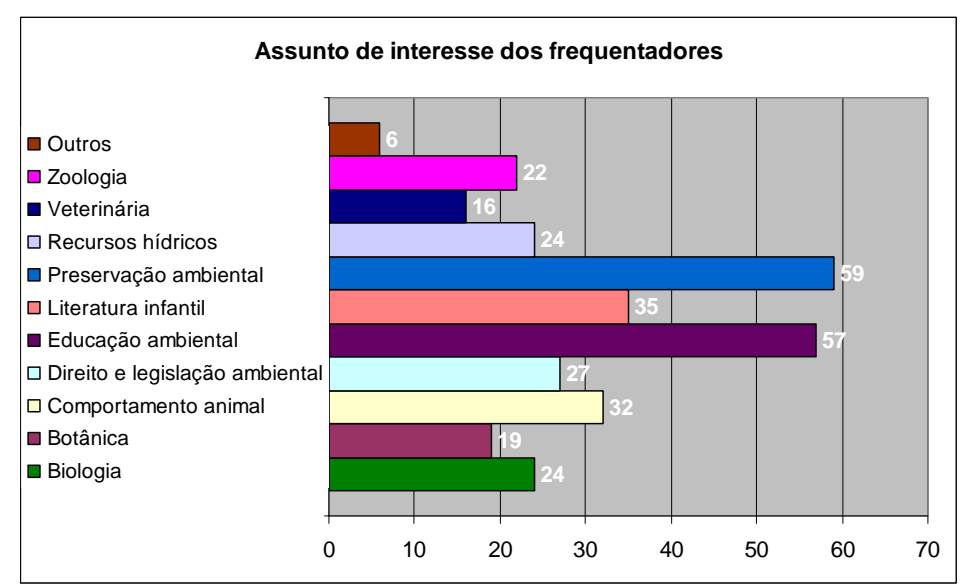

Figura 14 - Assuntos de interesse dos freqüentadores

Foi constatado que, mesmo aqueles que julgam ser desnecessária uma biblioteca no Zoológico, se interessam pelos assuntos listados no questionário, de acordo com a Figura 15:

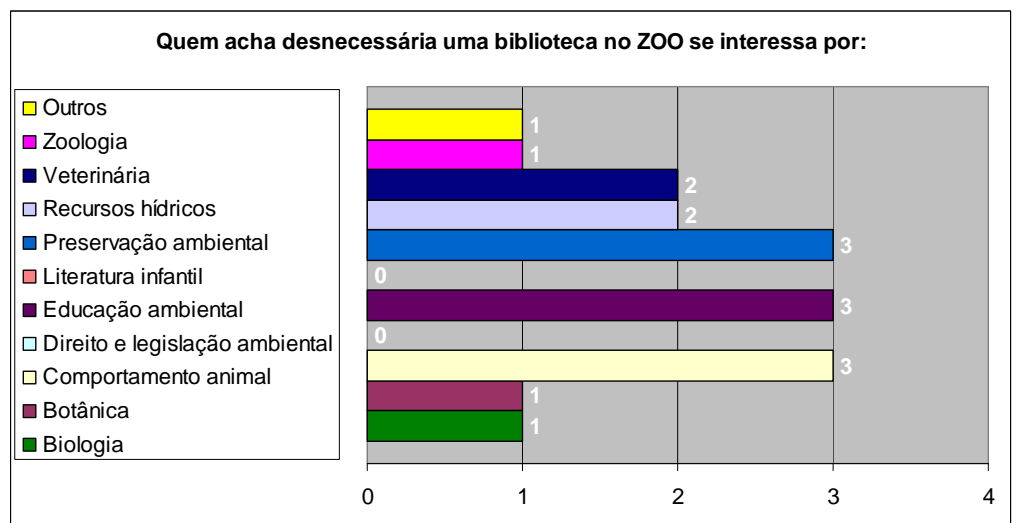

Figura 15 - Assuntos de interesse dos usuários que julgam desnecessária uma biblioteca no ZOO. 


\section{Utilização de Bibliotecas}

Com relação à utilização de bibliotecas em geral, 64\% fazem empréstimo de livros, 59\% as usam para pesquisa e estudo, e 40\% para ler livros. Verificase que apenas 3\% não utilizam bibliotecas, conforme Figura 16.

Pelo fato da questão ser de múltipla escolha, a porcentagem utilizada é em relação ao tamanho da amostra, que é de 100 frequentadores.

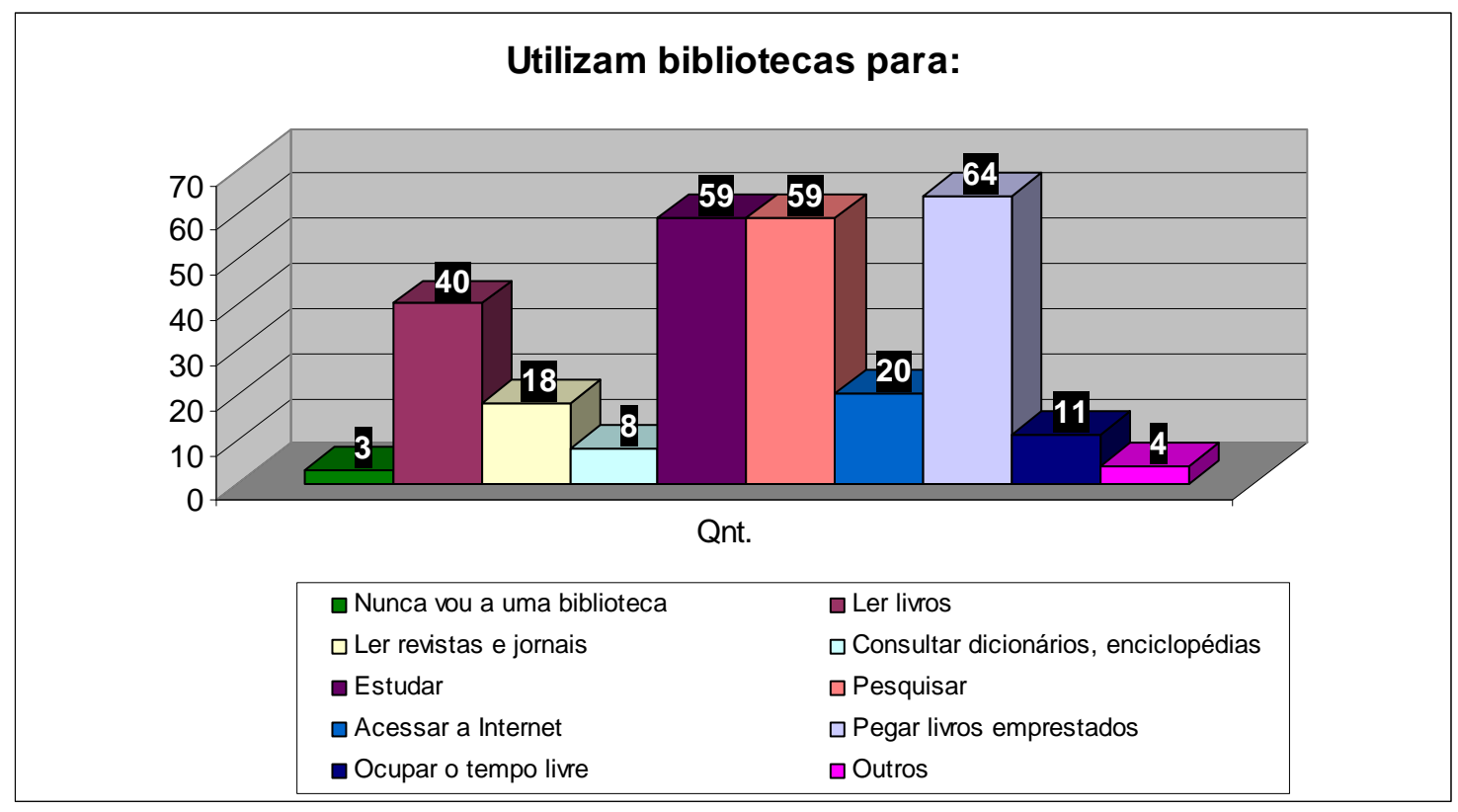

Figura 16 - Utilização de bibliotecas

\section{Sugestões dos frequentadores}

Apenas 55\% dos entrevistados responderam à questão número nove, o que pode ter ocorrido pelo fato da questão ser aberta e exigir maior empenho do respondente, porém alguns deram mais de uma sugestão. Por ter caráter qualitativo foi possível identificar de forma mais eficaz as necessidades dos usuários.

$15 \%$ das sugestões foram sobre as instalações físicas da biblioteca e, em sua maioria, eram a respeito do conforto e do ambiente agradável que deve ter a biblioteca. Houve uma sugestão de que o prédio fosse construído com materiais reciclados, e outra para que o prédio fosse sustentável, isto é, que não necessite de ar condicionado, aproveitando ao máximo a luminosidade e fossem criados ambientes ao ar livre. 
O maior número de sugestões (33\%) foram para que a biblioteca ofereça serviços voltados às crianças e aos alunos que frequentam o ZOO, como palestras educativas, oficinas, exposições e apresentação de vídeos.

A implementação de projetos de conscientização ambiental e a elaboração de campanhas de educação ambiental para visitantes em geral foram o segundo maior numero de sugestões (20\%), empatados com a indicação de acervo temático (especializado).

Alguns usuários (13\%) sugeriram que a Biblioteca faça uma boa campanha de divulgação quando estiver em funcionamento, já que muitos não sabiam da existem da antiga biblioteca.

Houve também um considerável número de sugestões (9\%) sobre a criação de uma Brinquedoteca ou Gibiteca, para uso das crianças.

Foi sugerido também que na Biblioteca esteja sempre presente um bibliotecário e que tenha materiais acessíveis aos deficientes visuais; que a biblioteca tenha convênios com universidades para fins de pesquisa e faça intercâmbio com outros zoológicos; e que seja voltada às necessidades dos funcionários e colaboradores do zoológico e não aos visitantes.

Indicaram também que Literatura faça parte do acervo e haja na Biblioteca acesso a internet e rede wireless.

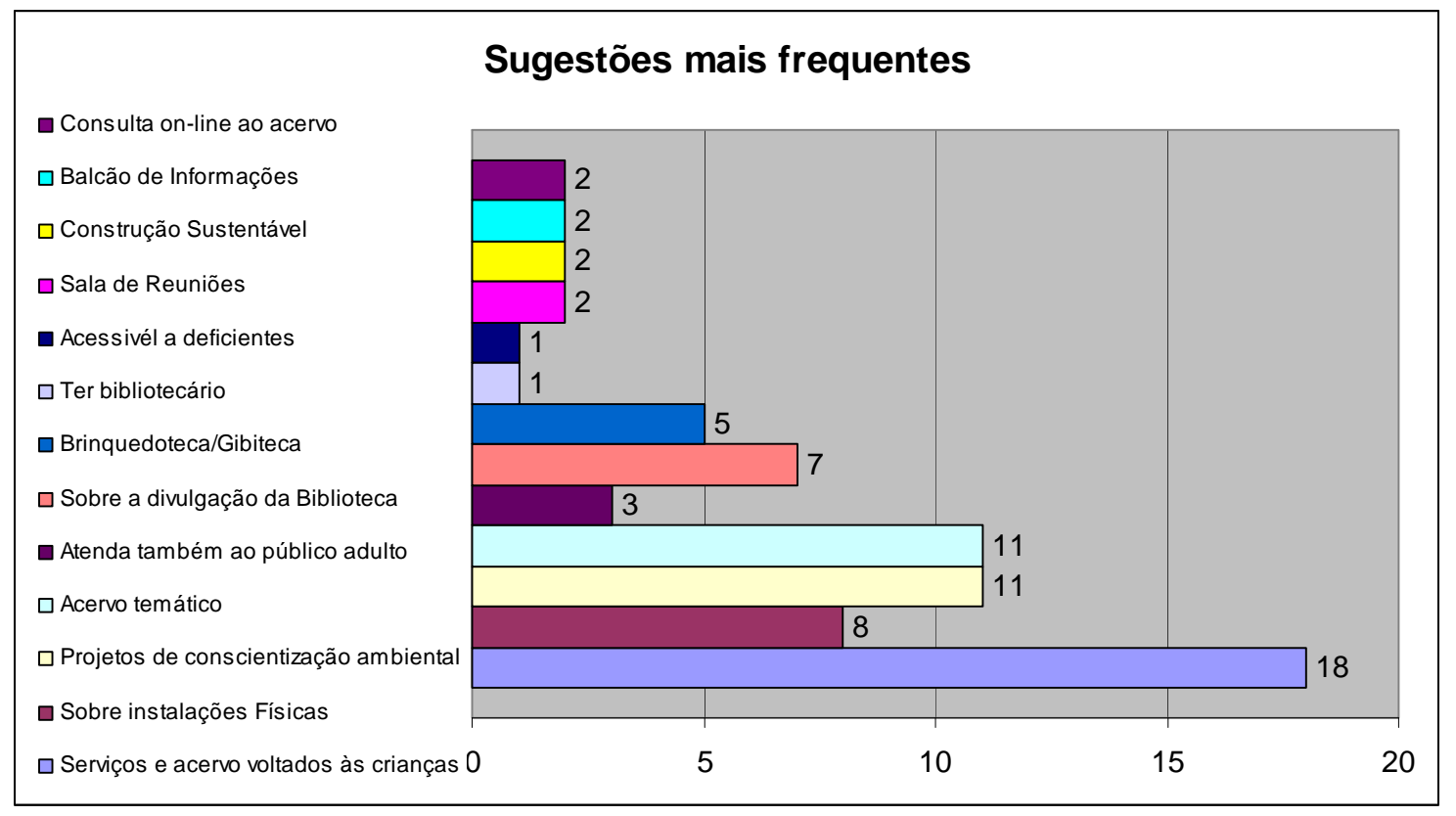

Figura 17 - Sugestões dos frequentadores 


\subsubsection{Funcionários e colaboradores}

Os questionários foram aplicados aleatoriamente a 25 funcionários e colaboradores do Zoológico de Brasília.

\section{Setor de trabalho}

Foram entrevistados funcionários de cinco departamentos do ZOO, sendo que 28\% pertencem à Superintendência Administrativa e Financeira Suafi, 24\% à Superintendência de Conservação e Pesquisa - Sucop, 20\% à Superintendência de Educação e Lazer - Suel, 16\% ao Gabinete da Presidência e $12 \%$ à Vigilância.

Dentre os respondentes se encontram a Ouvidora do ZOO, uma Superintendente, Chefes, Procuradores, Secretárias, Vigilantes, Assistentes e Auxiliares Administrativos e outros.

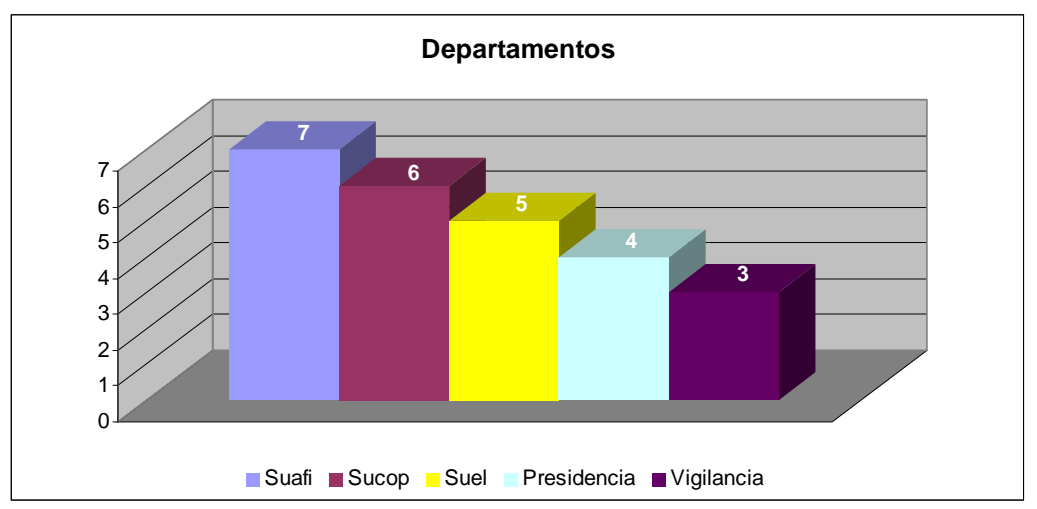

Figura 18 - Departamento

\section{Nível de instrução dos funcionários}

Como demonstra a Figura 19, 68\% dos funcionários possuem nível superior e apenas 8\% não possuem nível médio. Por meio da análise dos questionários pode-se verificar que as áreas de graduação dos entrevistados são: Administração, Biologia, Direito, História, Jornalismo, Pedagogia, Psicologia, Veterinária e Turismo. 


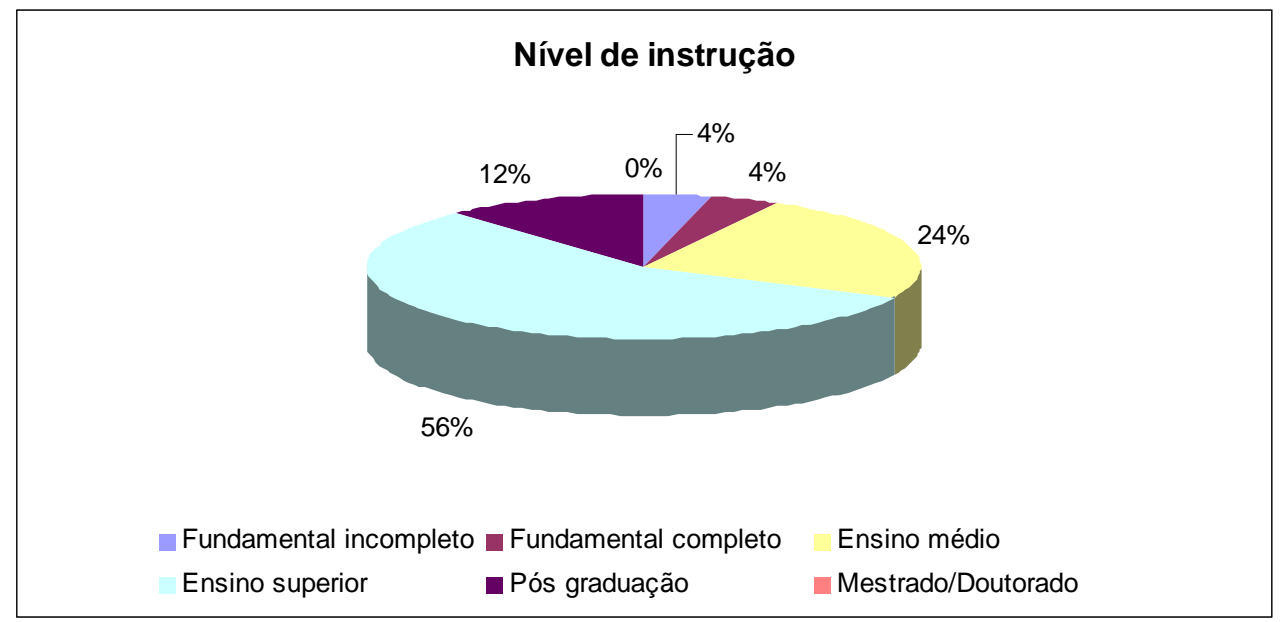

Figura 19 - Nível de instrução dos funcionários

\section{Importância da Biblioteca}

Pela Figura 20, percebe-se claramente que todos os entrevistados consideram importante a presença de uma biblioteca no Zoológico de Brasília.

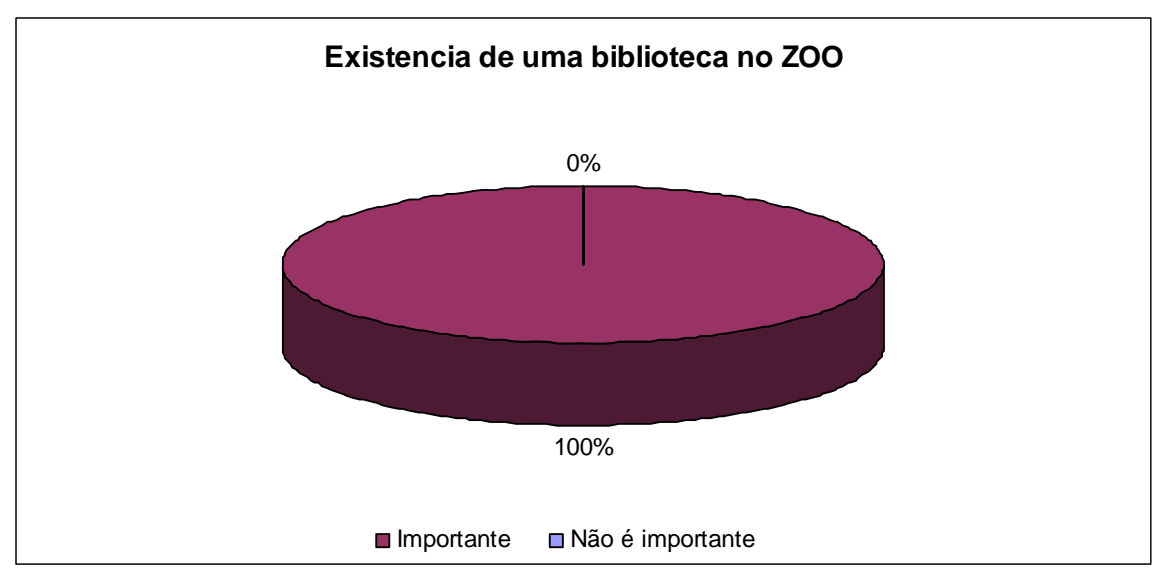

Figura 20 - Importância da Biblioteca

\section{Assuntos que devem constar no acervo}

Com relação aos assuntos que devem constar do acervo da Biblioteca, diversos assuntos foram escolhidos por 96\% dos entrevistados, como: 'Veterinária', 'Preservação ambiental', 'Educação ambiental' e 'Direito e Legislação Ambiental'. Foram assinalados por 92\% dos entrevistados dois assuntos: 'Zoologia' e 'Botânica'. 
Conforme mostra a figura 21, todos os assuntos foram marcados por 12 ou mais pessoas e apenas duas sugeriram outros assuntos, que foram 'Turismo', 'Zootecnia' e 'Enriquecimento ambiental', todos eles dentro da temática proposta pela Biblioteca.

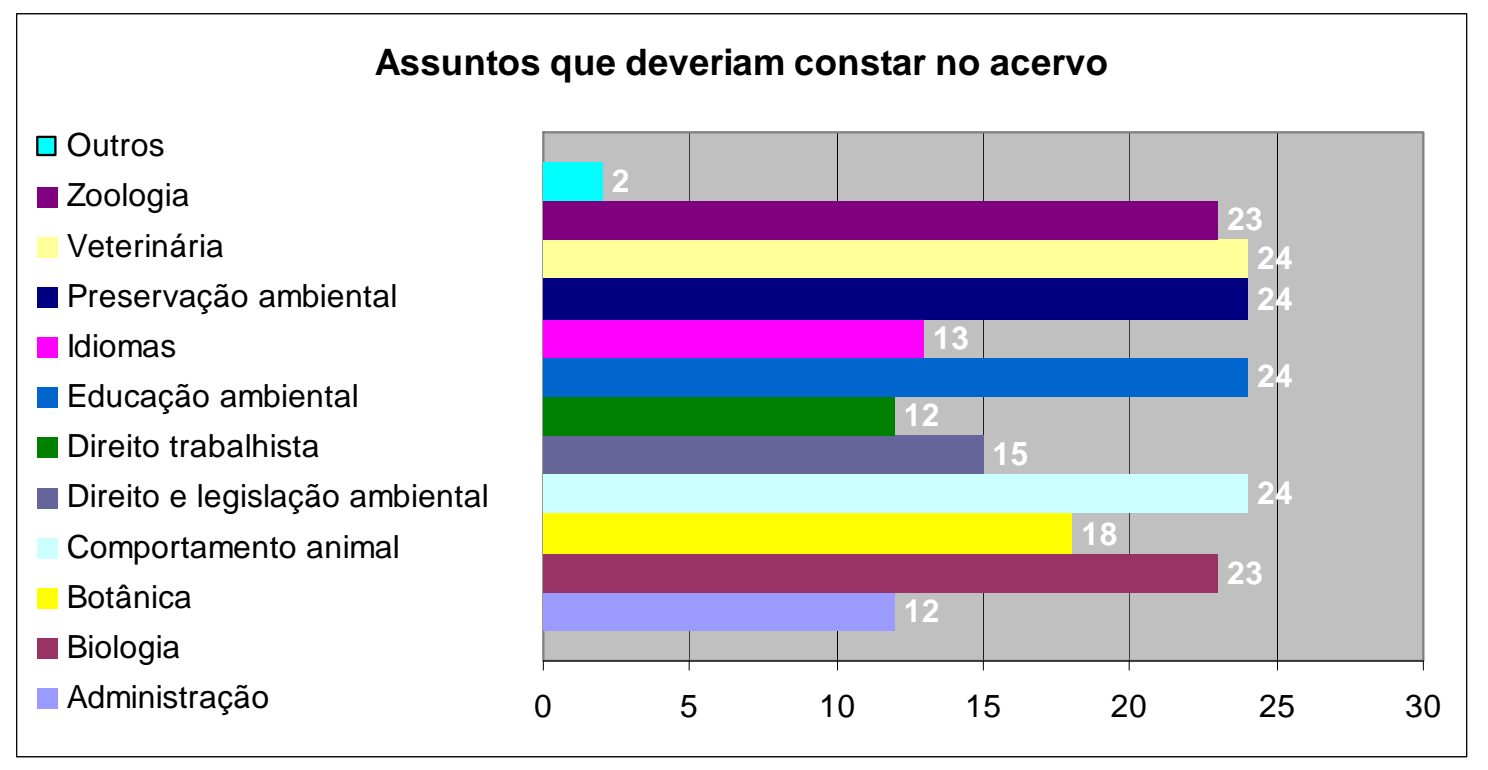

Figura 21 - Assuntos que devem constar no acervo

\section{Idiomas que lêem}

Apenas nove respondentes afirmaram ler em outra língua. Alguns deles lêem em mais de um idioma estrangeiro. Como se pode ver na Figura 22, o idioma mais marcado é o espanhol, seguido do inglês. Isso indica que a preocupação maior da Biblioteca deverá ser em adquirir documentos em língua portuguesa.

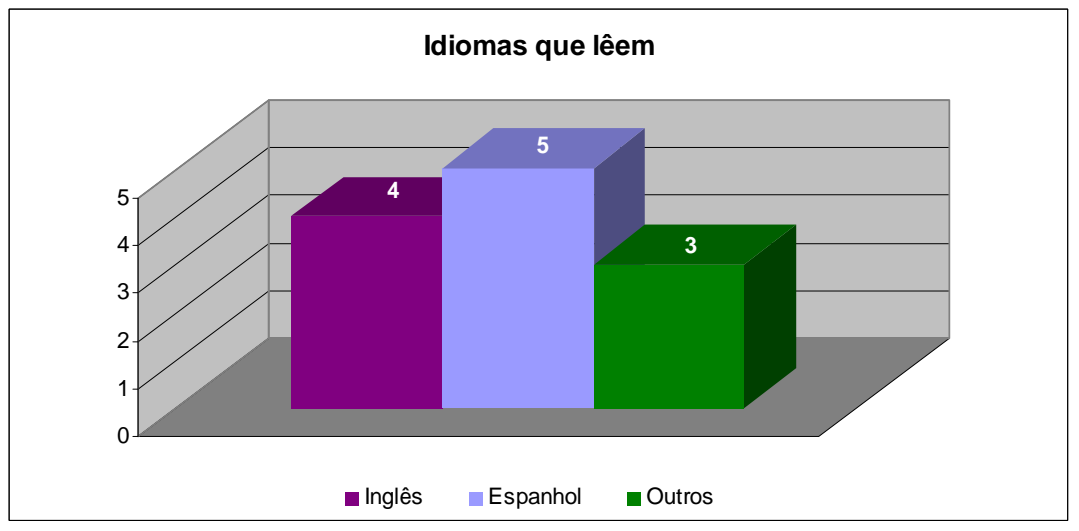

Figura 22 - Idiomas que lêem 


\section{Utilização da Biblioteca}

Quanto aos fins para que utilizariam a Biblioteca, a maioria dos respondentes (84\%) afirmou ser para 'aperfeiçoamento profissional', e 64\% para 'pesquisas particulares'. Nenhum deles marcou que não utilizaria a Biblioteca.

Pelo fato da questão ser de múltipla escolha, a porcentagem utilizada é em relação ao tamanho da amostra, que é de 25 funcionários e colaboradores.

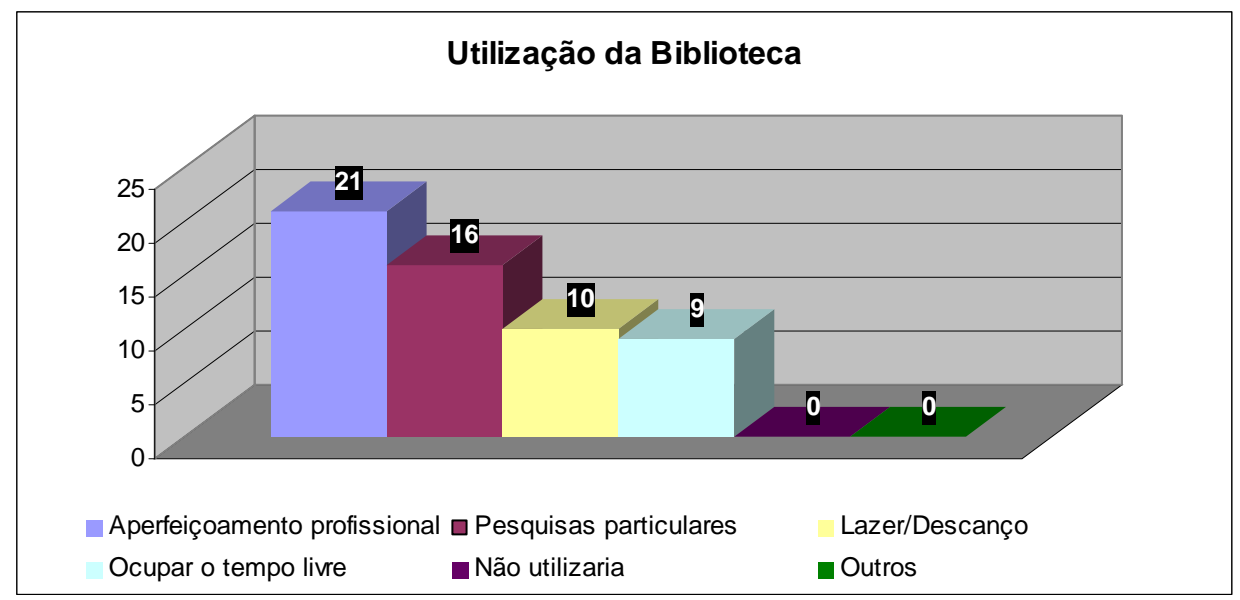

Figura 23 - Utilização da Biblioteca

\section{Serviços a serem oferecidos}

Com relação aos serviços que consideram mais importantes que a Biblioteca ofereça, conforme Figura 24, o empréstimo de livros foi marcado por $76 \%$ dos entrevistados, seguido de acesso a Internet, por $72 \%$. O serviço menos marcado foi o serviço de reprografia, por $48 \%$.

Esta questão é de múltipla escolha, como a anterior, por isso a porcentagem utilizada é em relação ao tamanho da amostra, que é de 25 funcionários e colaboradores. 


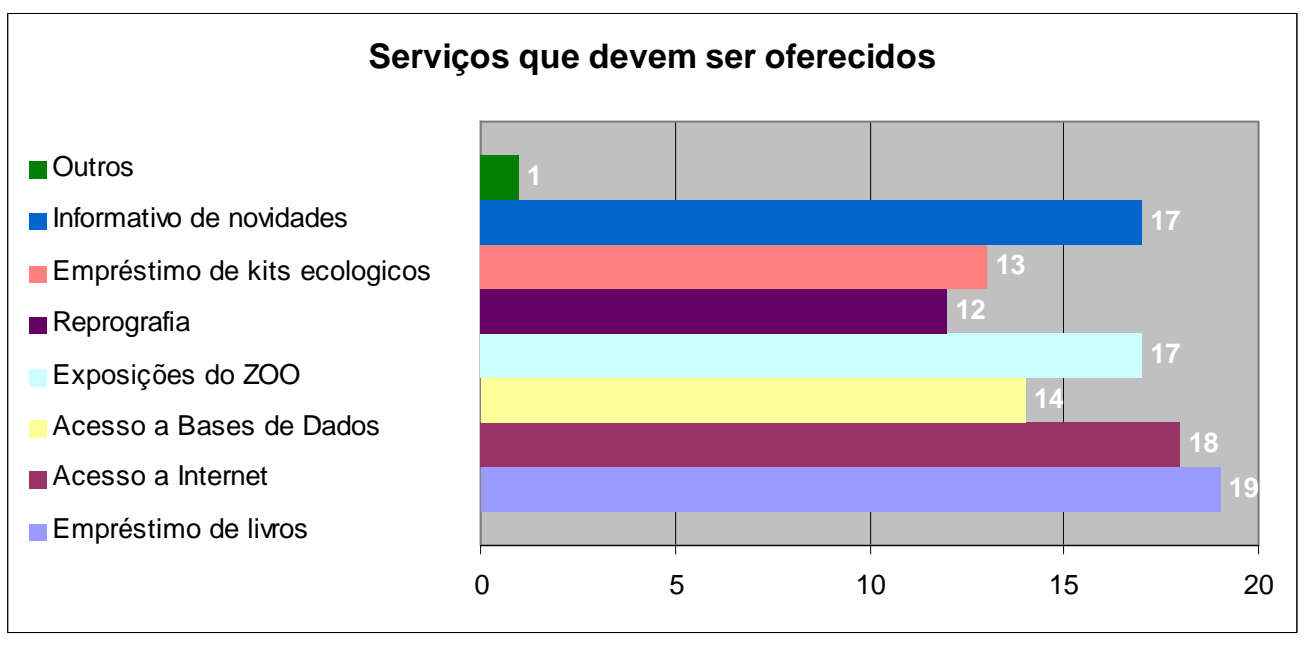

Figura 24 - Serviços a serem oferecidos

\section{Sugestões}

Dos 25 entrevistados, apenas oito deram sugestões para a Biblioteca, porém alguns deram mais de uma sugestão. Houve indicações de serviços, conteúdo do acervo e sobre o ambiente da Biblioteca. Foram elas:

- Existência de uma sala de estudos;

- Implantação de uma sala de acesso a Internet;

- Disponibilização de uma máquina de café expresso;

- Campanhas de doação para formação do acervo;

- Realização de palestras, seminários, filmes;

- Acervo temático para adultos, crianças e deficientes visuais;

- Implantação de uma Videoteca;

- Ambiente agradável com espaço para crianças;

- Foco no público infantil;

- Obtenção do certificado ISO de qualidade. 


\subsection{Proposta para estabelecimento dos serviços de informação aos usuários da BEZOO.}

Com base na revisão de literatura e nas pesquisas realizadas são feitas propostas, relacionadas a horário de funcionamento e dos serviços que deverão ser oferecidos por esta Biblioteca:

Horário de funcionamento:

Tendo em vista que o ZOO funciona de Terça a Domingo das 09:00h às 18:00h sugere-se que o horário de funcionamento da Biblioteca seja o mesmo.

Serviços a serem oferecidos:

Os serviços a serem oferecidos pela BEZOO serão:

- Consulta ao acervo, independente do suporte, a todos os frequentadores, visitantes e usuários da Biblioteca;

- Empréstimo domiciliar aos funcionários, com prévio cadastramento;

- Renovação de empréstimo, por via telefônica ou site da Biblioteca;

- Informações ao usuário, presencial, por telefone ou por email;

- Instruções de consulta ao catálogo e localização de materiais;

- Pesquisas bibliográficas;

- Informativo de novas aquisições, eventos e exposições, por cartazes na Biblioteca e demais dependências do Zoológico e por via web;

- Disseminação Seletiva da Informação para funcionários do ZOO.

- Exposições de periódicos e livros novos;

- Normalização de todos os documentos elaborados pelo ZOO;

- Repositório institucional das publicações oficiais do Zoológico, tanto os documentos de caráter interno como externo;

- Acesso a Internet;

- Acesso a Bases de Dados das áreas de interesse ao ZOO;

- Brinquedoteca;

- Gibiteca;

- Videoteca;

- Atividades de educação ambiental, principalmente para as crianças. 
A Biblioteca do Zoológico também promoverá eventos para seus usuários, como:

- Exposições do ZOO;

- Exibição de vídeos pertencentes ao acervo;

- Projetos de conscientização ambiental e esclarecimentos sobre as espécies, e outros.

Devido ao fato do Zoológico se localizar, distante das residências e do trabalho de seus frequentadores, a visita dos mesmos à Biblioteca poderá ser prejudicada. Para minorar esse problema propõe-se que a Biblioteca ofereça Serviços de Referência Virtual - SRV.

Segundo Ranganathan (1961, apud SILVA E BEUTTENMÜLLER, 2005, p. 79), Serviço de Referência "é o processo de estabelecer contato entre o leitor (usuário) e o documento (informação) de uma maneira pessoal". No novo contexto onde as bibliotecas passam a utilizar as tecnologias da web para entrar em contato com seu usuário, surge o Serviço de Referência Virtual como um recurso eletrônico que auxilia o usuário na busca pela informação. Este serviço atende os mesmos objetivos do Serviço de Referência tradicional, porém utiliza a Internet como um recurso que amplia o universo da informação e facilita o contato entre o bibliotecário e o usuário (SILVA E BEUTTENMÜLLER, 2005).

O SRV inclui a criação de um web site para a BEZOO que oferecerá os seguintes serviços:

- Catálogo on-line, onde será possível o acesso ao acervo;

- Renovação e reserva de documentos;

- Disponibilização de links de Bases de Dados e Redes conveniadas à Biblioteca;

- Acesso a publicações eletrônicas assinadas pela Biblioteca ou gratuitas;

- Atendimento, via correio eletrônico, por um bibliotecário de referência;

- Solicitação de pesquisa virtual por meio de formulários. 
Também como sugestão de Serviços de Referência Virtual recomendase a utilização de ferramentas da Web 2.0 para garantir maior contato e interação com o usuário externo. As ferramentas indicadas são:

- Blog;

- Twitter;

- Delicious;

- Serviços de mensagem instantânea.

O Blog terá o objetivo de divulgar as novidades da Biblioteca e assuntos de relevância para os usuários. O Twitter servirá como meio de comunicação com usuários e divulgação da biblioteca. O Delicious é a ferramenta onde a Biblioteca divulgará os links de sites, bibliotecas, bases de dados entre outros, que possam interessar aos usuários. O link da conta da Biblioteca no Delicious será adicionado ao Blog da mesma, a fim de divulgar esse serviço aos usuários. Os serviços de mensagem instantânea serão uma conta no MSN, que deverá ficar online durante o horário de funcionamento da Biblioteca, e no Plugoo que será associada à conta do MSN. Tais ferramentas fornecem widgets que permitem aos usuários conversarem em tempo real com o bibliotecário que estiver online, sem ser necessário possuir conta em programas de mensagem instantânea. Os widgets serão adicionados ao Site e ao Blog da Biblioteca.

Os serviços propostos, tanto os tradicionais como os virtuais, pretendem minimizar a distância entre o usuário e a informação, visando atender às necessidades consciente e visceral de seus usuários. 


\section{Conclusão}

A partir da revisão de literatura, do estudo de caso e do resultado das entrevistas e dos questionários foi possível conhecer a realidade da Fundação Jardim Zoológico de Brasília.

A revisão de literatura confirma a necessidade que as organizações possuem de ter em sua estrutura uma biblioteca especializada, voltada para a sua área específica de atuação, para atendimento aos seus usuários potenciais e reais. O estudo de caso revelou o contexto no qual o Jardim Zoológico de Brasília está inserido, demonstrando sua situação atual. Neste estudo, identificou-se que essa Fundação possuía uma biblioteca que pegou fogo em julho de 2007. A administração do Zoológico percebeu a necessidade da sua estrutura contar com uma unidade de informação especializada, voltada para o atendimento das necessidades informacionais de seus funcionários e frequentadores.

$\mathrm{Na}$ pesquisa de campo, percebeu-se que a extinta biblioteca era bastante utilizada por estudantes do ensino fundamental e médio em suas pesquisas escolares sobre a fauna, flora e o bioma cerrado. Naquele período, não era tida como referência para os pesquisadores e funcionários do Zoológico, pois não possuía acervo especializado que atendesse às necessidades informacionais do seu público interno. Ou seja, a antiga biblioteca não conseguia cumprir com todos os objetivos da Fundação Jardim Zoológico de Brasília, que é o de pesquisa, pois, a mesma não possuía estrutura para tal.

Além disso, ficou constatado que o Brasil não possui bibliotecas em Zoológicos que possam ser citadas como referência quando se é estudado o tema Bibliotecas Especializadas em Zoológicos. O Brasil não possui mais do que simples estantes que servem de depósito dos documentos referentes às suas instituições.

Esta monografia tem o principal objetivo de conhecer as necessidades de informação dos frequentadores do Zoológico e dos seus funcionários. $\mathrm{Na}$ interpretação dos dados obtidos, grande maioria dos entrevistados alegou que a distância existente, devido à localização do Zoológico, entre a biblioteca e as suas residências era o principal empecilho de acesso à mesma. 
A principal solução encontrada para resolver tal problema, foi a criação, na Biblioteca, do Serviço de Referência Virtual, juntamente com os serviços tradicionais da Biblioteca, citados nas propostas. Acredita-se que tais serviços serão capazes de sanar as dificuldades de seus frequentadores.

Vários frequentadores e funcionários do Zoológico sugeriram que a Biblioteca deve atender ao público infantil, principal frequentador do Zoológico, bem como aos estudantes, pesquisadores, técnicos e funcionários.

O acervo deve ser especializado na área de Zoologia, Educação Ambiente, Veterinária e afins, em diferentes níveis, capaz de atender aos vários tipos de usuários, contando com informações em vários suportes, inclusive multimídia.

A razão de se ter um acervo especializado, contendo também informações científicas e técnicas, é devido ao atendimento das necessidades de informação dos seus funcionários, pesquisadores e técnicos, além de outras instituições que trabalham com ou sobre a fauna e a flora do Distrito Federal.

O importante é que o acervo, juntamente com a infra-estrutura da Biblioteca e os serviços propostos, proporcionem aos seus usuários o acesso e uso da informação que necessitam.

Portanto, a Fundação Jardim Zoológico de Brasília, como instituição que favorece e incentiva a pesquisa e o desenvolvimento social deve possuir em sua estrutura uma unidade de informação que ajude a cumprir seus objetivos, ampliando o valor e o prestígio da Instituição dentro do cenário local e nacional, além de ser a guardiã da sua memória institucional. 


\section{Referências}

ASSOCIAÇÃO BRASILEIRA DE NORMAS TÉCNICAS. Informação e documentação - referências - apresentação: NBR6023:2005. Rio de Janeiro: ABNT, 2005.

. Informação e documentação - numeração progressiva das seções de um documento escrito - apresentação: NBR6024:2003. Rio de Janeiro: ABNT, 2003.

. Informação e documentação - sumário - apresentação:

NBR6027:2003. Rio de Janeiro: ABNT, 2003.

. Informação e documentação - resumo - apresentação:

NBR6028:2003. Rio de Janeiro: ABNT, 2003.

. Informação e documentação - citações em documentos -

apresentação: NBR10520:2002. Rio de Janeiro: ABNT, 2002

Informação e documentação - trabalhos acadêmicos - apresentação:

NBR14724:2005. 2.ed. Rio de Janeiro: ABNT, 2005

ALMEIDA JÚNIOR, Oswaldo Francisco de. Serviço de auxílio aos usuário. Disponível em: <http://www.ofaj.com.br/disciplina_conteúdo.php?cod=33> Acesso em: 09/03/2009.

BORGES, Maria Alice Guimarães. A compreensão da sociedade da informação. Ciência da Informação, Brasília, v. 29, n. 3, p. 25-32, set./dez. 2000.

BAPTISTA, Sofia Galvão; CUNHA, Murilo Bastos. Estudos de usuários: visão global dos métodos de coleta de dados. Perspectivas em Ciência da Informação, v. 12, n. 2, p. 168-184, maio/ago. 2007.

CEZARINO, Maria A. da Nóbrega. Bibliotecas especializadas, centros de documentação, centros de análise da informação: apenas uma questão de terminologia? Revista da Escola de Biblioteconomia da UFMG, Belo Horizonte, v.7, n. 2, p. 218-241, set. 1978. 
FIGUEIREDO, Nice. Bibliotecas universitárias e especializadas: paralelos e contrastes. Revista de Biblioteconomia de Brasília, v. 7, n. 1, jan-jun. 1979.

JAMIL, George Leal; NEVES, Jorge Tadeu de Ramos. A era da informação: considerações sobre o desenvolvimento das tecnologias da Informação. Perspectiva em ciência da informação, Belo Horizonte, v. 5, n. 1, p. 41-53. jan./jun. 2000.

LARA, M. L. G. de; CONTI, V. L. Disseminação da informação e usuários. São Paulo em Perspectiva, São Paulo, v. 17, n. 3-4, p. 26-34, 2003.

MIRANDA, Ana Cláudia Carvalho de. Formação e desenvolvimento de coleções em bibliotecas especializadas. Informação \& Sociedade: estudos, João Pessoa, v.17, n.1, p. 87-94, jan./abr. 2007.

NEHMY, Rosa Maria Quadros; PAIM, Isis. Repensando a sociedade da informação. Perspectiva em ciência da informação, v. 7, n. 1, p. 9-21, jan./jun. 2002.

NOCETTI, Milton A. Disseminação seletiva da informação: teoria e prática. Brasília: ABDF, 1980.

OLIVEIRA, Maria O. E. de. A Disseminação da Informação na construção do conhecimento e na formação da cidadania. In: Proceedings XIX Congresso Brasileiro de Biblioteconomia e Documentação, 1, 2000. Disponível em: <http://dici.ibict.br/archive/00000776/>. Acesso em: 27 maio 2009.

SALASÁRIO, Maria G. da Cunha. Biblioteca especializada e informação: da teoria conceitual à prática na biblioteca do Laboratório de Mecânica de Precisão - LMP/UFSC. R. ACB: Biblioteconomia em Santa Catarina, v. 5, n. 5, p. 104-119, 2000.

SOUTO, Leonardo F. Disseminação seletiva de informações: discussão de modelos eletrônicos. Encontros Bibli: Revista Eletrônica de Biblioteconomia e Ciência da Informação, Florianópolis, n. esp., p. 60-74, $1^{\circ}$ sem. 2006.

SOUTO, Leonardo F. Disseminação seletiva da informações na área da saúde: o caso do web site Amedeo. Revista Brasileira de educação médica, Rio de Janeiro, v. 30, n. 2, p. 4-13, 2006. 
SILVA, Alzira K. A. da; BEUTTENMÜLLER, Zailton F. O Serviço de Referência Virtual nas bibliotecas virtuais da Região Nordeste. Encontros Bibli: revista eletrônica de Biblioteconomia e Ciência da Informação, Florianópolis, n. 20, $2^{\circ}$ sem. 2005.

TARGINO, Maria das Graças. Bibliotecas Universitárias e especializadas de São Luís. Revista de Biblioteconomia de Brasília, Brasília, v. 16, n. I, p. 19-32, jan./jun. 1988.

TERUEL, Aurora González. Los estudios de necesidades y usos de la información: fundamentos y perspectivas actuales. Espanha: Ediciones Trea, 2005.

VOLPATO, Sílvia M. Berté; BORENSTEIN, Carlos R. A trajetória de uma biblioteca especializada: o caso da biblioteca do curso de pós-graduação em administração da UFSC. Revista de Ciência da Administração, Santa Catarina, ano 2, n. 4. set. 2000.

Dados sobre o Distrito Federal, disponível em:

<http://www.distritofederal.df.gov.br> Acesso em: 29/04/2009.

Histórico do ZOO, disponível em: <http://www.zoo.df.gov.br> Acesso em: 04/05/2009. 


\section{Glossário}

Blog: "página pessoal ou corporativa, geralmente escrita em primeira pessoa. É caracterizada por uma escrita informal, e traz experiências pessoais de seus autores". ${ }^{1}$

Delicious: É um tipo bookmarking social, é o termo mais conhecido em português como marcador, que permite a marcação de páginas na internet que sejam de interesse do usuário.

MSN messenger: É um tipo de serviço de mensagem instantânia. Os serviços de mensagens instantâneas (instant messaging, IM) se tornou um dos maiores trunfos da web 1.0 e uma das ferramentas que mais evoluiu através dos anos, ajudando a consolidar o termo web 2.0 devido a certas características que começaram a apresentar conforme evoluíam.

Plugoo: é uma ferramenta online feita para colocar você em contato com os visitantes do seu site/blog, em uma conversa em tempo real através do seu Instant Messenger. Ele se comunica com vários serviços diferentes, como MSN,Yahoo! Messenger, AIM, GoogleTalk, Jabber ou ICQ.

Twitter: um microblog que permite aos usuários postarem mensagens de tamanho limitado sobre "o que você está fazendo agora" e se comunicarem em tempo real com pessoas de sua rede ou amigos, e ao mesmo tempo saber o que essas pessoas estão fazendo.

Web 2.0: "Web 2.0 é a mudança para uma internet como plataforma, e um entendimento das regras para obter sucesso nesta nova plataforma. Entre outras, a regra mais importante é desenvolver aplicativos que aproveitem os efeitos de rede para se tornarem melhores quanto mais são usados pelas pessoas, aproveitando a inteligência coletiva."

Widgets: Widgets ou web widgets são pequenas aplicações online que podem ser embutidas em sites e blogs a fim de exibir conteúdos de outros sites, tais como notícias, previsões do tempo, cotações de bolsas de valores, mapas virtuais ou resultados de jogos.

\footnotetext{
${ }^{1}$ PANISSI, Fernando. Dicionário da nova internet. Blog Tira Dúvidas. Disponível em:<http://colunas.g1.com.br/tiraduvidas/2007/10/09/dicionario-da-nova-internet/>. Acesso em: 13 maio 2009.

2 (Tim O'Reilly o criador do termo web 2.0 )
} 
Universidade de Brasília - UnB

Faculdade de Economia, Administração, Contabilidade, Ciência da Informação e

Documentação - FACE

Departamento de Ciência da Informação e Documentação - CID

\section{Questionário - Bibliotecas}

Prezado colaborador,

Este questionário tem por objetivo coletar dados sobre uma biblioteca para o Zoológico de Brasília, como parte de um a monografia para a conclusão do curso de Bibl ioteconomia na universidade de Brasília. Muito obrigada pela sua colaboração.

\section{IDENTIFICAÇÃO}

- Nome da Biblioteca:

- Instituição a que pertence:

- Endereço:

- Telefone: em ail:

\section{CARACTERIZAÇÃO}

1- A Biblioteca possui recursos financeiros próprios, em caso contrário, como é mantida?

2- Tem autonomia sobre o uso dos recursos financeiros?

3- Número total de funcionários que a Biblioteca possui? (Bibliotecários, estagiários, assistentes etc.)

4- Quais os setores da Biblioteca? (Organograma, se tiver)

5- Número de bibliotecários por setor:

6- Tamanho do acervo: (livro periódicos e outros)

7- Principais assuntos solicitados:

8- Público alvo da Biblioteca: 
( ) Público interno

( ) Público externo

\section{INFORMAÇÕES TÉCNICAS}

9- Existe uma política de seleção de acervo?

( ) $\operatorname{Sim}$ ( ) Não

10- Como é feita a aquisição do acervo? (pode haver mais de uma resposta)

( ) Compra ( ) Doação ( ) Intercâmbio / Permulta

11- Utiliza algum software gerenciador de bibliotecas? Qual?

12-Qual o sistema de classificação utilizado?

13- Usa algum tipo de vocabulário controlado para indexação?

14- Marque os serviços oferecidos pela biblioteca:
( ) Empréstimo de livros
( ) Informativo de novidades
( ) Acesso a internet
( ) Acesso a Bases de Dados
( )Espaço para exposições do ZOO

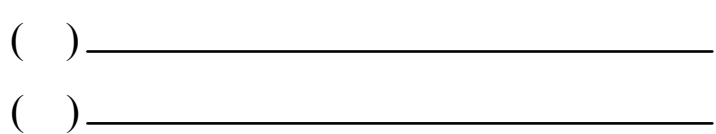
( ) Serviço de reprografia (Xerox)
( )
( ) Empréstimo de kits ecológicos p/ escolas

15-Existe alguma estratégia de marketing para a Biblioteca? Quais?

16- A Biblioteca produz alguma publicação? Qual?

17- Oferece algum outro tipo de produto? Qual? 
Universidade de Brasília - UnB

Faculdade de Economia, Administração, Contabilidade, Ciência da Informação e

Documentação - FACE

Departamento de Ciência da Informação e Documentação - CID

\section{Questionário - Freqüentadores}

Prezado colaborador,

$\mathrm{N}^{\mathrm{o}}$ :

Este questionário tem por objetivo coletar dados sobre uma biblioteca para o Zoológico de Brasília, como parte de um a monografia para a conclusão do curso de Bibl ioteconomia na universidade de Brasília. Muito obrigada pela sua colaboração.

1- Qual sua idade?

2- Qual sua nível de instrução?

( ) Ensino fundamental incompleto

( ) Ensino superior completo

( ) Ensino fundamental completo

( ) Pós-graduação

( ) Ensino médio incompleto

( ) Mestrado/Doutorado

( ) Ensino médio completo

( ) Não sei ler

3- Com que freqüência vem ao Zoológico?

( ) Toda semana

( ) Duas vezes ao ano

( ) Duas vezes ao mês

( ) Uma vez ao ano

( ) Uma vez ao mês

( ) Esta é a primeira vez

( ) A cada três meses

4- Suas visitas costumam ser em:

( ) Dias de semana

( ) Fins de semana

5- O que você acha de ter uma biblioteca/ biblioteca infantil para o Zoológico?

( ) Ótimo, eu frequentaria

( ) Bom, mas não frequentaria

( ) Ótimo, mas não frequentaria

( ) Acho desnecessário

( ) Bom, eu frequentaria

( ) Não acho nada

6- Marque os assuntos que mais interessam a você?
( ) Zoologia
( ) Biologia 
( ) Comportamento animal

( ) Preservação ambiental

( ) Botânica

( ) Veterinária

( ) Literatura infantil
( ) Educação ambiental

( ) Recursos hídricos

( ) Direito e legislação ambiental

( ) Outros:

7- Você lê em outro idioma? Qual:

8- Para que fins utiliza mais frequentemente uma biblioteca?

( ) Nunca vou a uma biblioteca

( ) Pesquisar

( ) Ler livros

( ) Acessa a internet

( ) Ler revistas e jornais

( ) Pegar livros emprestados

( ) Consultar dicionários, enciclopédias etc. ( ) Ocupar o tempo livre

( ) Estudar

( ) Outros:

9- Qual sua sugestão para a nova biblioteca que vai ser criada no Zoológico? 
Universidade de Brasília - UnB

Faculdade de Economia, Administração, Contabilidade, Ciência da Informação e

Documentação - FACE

Departamento de Ciência da Informação e Documentação - CID

\section{Questionário - Funcionários}

Prezado colaborador,

$\mathrm{N}^{\mathrm{o}}$ :

Este questionário tem por objetivo coletar dados sobre uma biblioteca para o Zoológico de Brasília, como parte de um a monografia para a conclusão do curso de Bibl ioteconomia na universidade de Brasília. Muito obrigada pela sua colaboração.

1- Superintendência de atuação:

( ) Superintendência Administrativa e Financeira - Suafi

( ) Superintendência de Conservação e Pesquisa - Sucop

( ) Superintendência de Educação e Lazer - Suel

2- Qual sua função no ZOO?

Departamento:

3- Qual seu nível de instrução:

( ) Ensino fundamental incompleto

( ) Pós-graduação. Área:

( ) Ensino fundamental completo

( ) Mestrado/Doutorado. Área:

( ) Ensino médio

( ) Não sei ler

( ) Ensino superior. Curso:

4- Considera importante a existência de uma biblioteca especializada e infantil no Zoológico?

( ) $\operatorname{Sim}$

( ) Não

5- Quais assuntos são importantes para ter no acervo da Biblioteca do Zoológico?

( ) Zoologia

( ) Comportamento animal

( ) Preservação ambiental

( ) Botânica

( ) Veterinária

( ) Biologia
( ) Educação ambiental

( ) Direito e legislação ambiental

( ) Direito trabalhista

( ) Administração

( ) Idiomas

( ) Outros: 
6- Você lê em outro idioma? Qual:

7- Você utilizaria a Biblioteca do Zoológico para:
( ) Aperfeiçoamento profissional
( ) Ocupar o tempo livre
( ) Pesquisas particulares
( ) Não utilizaria
( ) Lazer/Descanço
( ) Outros:

8- Quais os serviços que você considera importante que a Biblioteca deva oferecer?

( ) Empréstimo de livros

( ) Acesso a Internet

( ) Acesso a Bases de Dados

( ) Exposições do Zoológico
( ) Serviço de reprografia (Xerox)

( ) Empréstimo de kits ecológicos p/ escolas

( ) Informativo de novidades

( ) Outros:

9- Sugestões para a nova Biblioteca a ser criada no Zoológico: 